\title{
Partitioning of $\mathrm{NH}_{3}-\mathrm{NH}_{4}{ }^{+}$in the Southeastern U.S.
}

\author{
Bin Cheng ${ }^{1}$, Lingjuan Wang-Li ${ }^{2, *} \mathbb{C}$, Nicholas Meskhidze ${ }^{3}$, John Classen ${ }^{2} \oplus$ and Peter Bloomfield ${ }^{4}$ \\ 1 Oak Ridge Institute for Science and Education (ORISE), Postdoctoral Research Participant at U.S. EPA, \\ Research Triangle Park, Oak Ridge, NC 27709, USA; chengbin0228@gmail.com \\ 2 Department of Biological and Agricultural Engineering, North Carolina State University, \\ Raleigh, NC 27695, USA; classen@ncsu.edu \\ 3 Department of Marine Earth and Atmospheric Science, North Carolina State University, \\ Raleigh, NC 27695, USA; nicholas_meskhidze@ncsu.edu \\ 4 Department of Statistics, North Carolina State University, Raleigh, NC 27695, USA; \\ PeterBloomfield@bellsouth.net \\ * Correspondence: lwang5@ncsu.edu
}

Citation: Cheng, B.; Wang-Li, L.;

Meskhidze, N.; Classen, J.;

Bloomfield, P. Partitioning of $\mathrm{NH}_{3}-\mathrm{NH}_{4}{ }^{+}$in the Southeastern U.S. Atmosphere 2021, 12, 1681. https:// doi.org/10.3390/atmos12121681

Academic Editors: Theodora Nah, Shaojie Song and Zongbo Shi

Received: 3 November 2021

Accepted: 13 December 2021

Published: 15 December 2021

Publisher's Note: MDPI stays neutral with regard to jurisdictional claims in published maps and institutional affiliations.

Copyright: (c) 2021 by the authors. Licensee MDPI, Basel, Switzerland. This article is an open access article distributed under the terms and conditions of the Creative Commons Attribution (CC BY) license (https:/ / creativecommons.org/licenses/by/ $4.0 /)$.
Abstract: The formation of inorganic fine particulate matter (i.e., $\mathrm{iPM}_{2.5}$ ) is controlled by the thermodynamic equilibrium partitioning of $\mathrm{NH}_{3}-\mathrm{NH}_{4}{ }^{+}$. To develop effective control strategies of $\mathrm{PM}_{2.5}$, we aim to understand the impacts of changes in different precursor gases on $\mathrm{PPM}_{2.5}$ concentrations and partitioning of $\mathrm{NH}_{3}-\mathrm{NH}_{4}{ }^{+}$. To understand partitioning of $\mathrm{NH}_{3}-\mathrm{NH}_{4}{ }^{+}$in the southeastern U.S., responses of $\mathrm{iPM}_{2.5}$ to precursor gases in four seasons were investigated using field measurements of $\mathrm{iPM}_{2.5}$, precursor gases, and meteorological conditions. The ISORROPIA II model was used to examine the effects of changes in total ammonia (gas + aerosol), total sulfuric acid (aerosol), and total nitric acid (gas + aerosol) on $\mathrm{iPM}_{2.5}$ concentrations and partitioning of $\mathrm{NH}_{3}-\mathrm{NH}_{4}{ }^{+}$. The results indicate that reduction in total $\mathrm{H}_{2} \mathrm{SO}_{4}$ is more effective than reduction in total $\mathrm{HNO}_{3}$ and total $\mathrm{NH}_{3}$ to reduce $\mathrm{iPM}_{2.5}$ especially under $\mathrm{NH}_{3}$-rich condition. The reduction in total $\mathrm{H}_{2} \mathrm{SO}_{4}$ may change partitioning of $\mathrm{NH}_{3}-\mathrm{NH}_{4}{ }^{+}$towards gas-phase and may also lead to an increase in $\mathrm{NO}_{3}{ }^{-}$under $\mathrm{NH}_{3}$-rich conditions, which does not necessarily lead to full neutralization of acidic gases $(\mathrm{pH}<7)$. Thus, future reduction in $\mathrm{iPM}_{2.5}$ may necessitate the coordinated reduction in both $\mathrm{H}_{2} \mathrm{SO}_{4}$ and $\mathrm{HNO}_{3}$ in the southeastern U.S. It is also found that the response of $\mathrm{PPM}_{2.5}$ to the change in total $\mathrm{H}_{2} \mathrm{SO}_{4}$ is more sensitive in summer than winter due to the dominance of $\mathrm{SO}_{4}{ }^{2-}$ salts in iPM 2.5 and the high temperature in summer. The $\mathrm{NH}_{3}$ emissions from Animal Feeding Operations (AFOs) at an agricultural rural site (YRK) had great impacts on partitioning of $\mathrm{NH}_{3}-\mathrm{NH}_{4}{ }^{+}$. The Multiple Linear Regression (MLR) model revealed a strong positive correlation between cation- $\mathrm{NH}_{4}{ }^{+}$and anions- $\mathrm{SO}_{4}{ }^{2-}$ and $\mathrm{NO}_{3}{ }^{-}$. This research provides an insight into $\mathrm{PM}_{2.5}$ formation mechanism for the advancement of $\mathrm{PM}_{2.5}$ control and regulation in the southeastern U.S.

Keywords: inorganic $\mathrm{PM}_{2.5}$; precursor gas; thermodynamic equilibrium modeling

\section{Introduction}

Particulate matter (PM) with aerodynamic diameter less than or equal to $2.5 \mu \mathrm{m}$ (i.e., $\mathrm{PM}_{2.5}$ ) causes adverse impacts on the environment and human health [1-5]. In general, $\mathrm{PM}_{2.5}$ consists of inorganic ions, organic carbon (OC), elemental carbon (EC), various elements, and unclassified components [6-10]. Particulate matter can be classified as primary and secondary aerosol based on formation processes. Primary $\mathrm{PM}_{2.5}$ is directly emitted from emission sources while secondary $\mathrm{PM}_{2.5}$ is mainly formed through various chemical reactions and atmospheric processes [11-13]. The formation of the secondary inorganic $\mathrm{PM}_{2.5}\left(\mathrm{iPM}_{2.5}\right)$ is largely controlled by the chemical reactions between various precursor gases [14]. Ammonia $\left(\mathrm{NH}_{3}\right)$ neutralizes acidic species (e.g., nitric acid $\left(\mathrm{HNO}_{3}\right)$, sulfuric acid $\left(\mathrm{H}_{2} \mathrm{SO}_{4}\right)$, and hydrochloric acid $\left.(\mathrm{HCl})\right)$ to form ammonium $\left(\mathrm{NH}_{4}^{+}\right)$salts, and this dynamic process is called gas-particle partitioning of $\mathrm{NH}_{3}-\mathrm{NH}_{4}^{+}$[15]. In the atmosphere, secondary $\mathrm{iPM}_{2.5}$ mainly includes ammonium nitrate $\left(\mathrm{NH}_{4} \mathrm{NO}_{3}\right)$, ammonium 
sulfate $\left(\left(\mathrm{NH}_{4}\right)_{2} \mathrm{SO}_{4}\right)$, and ammonium chloride $\left(\mathrm{NH}_{4} \mathrm{Cl}\right)$ and may account for a large portion of total $\mathrm{PM}_{2.5}$ [16-21]. Depending upon the availability of $\mathrm{NH}_{3}, \mathrm{H}_{2} \mathrm{SO}_{4}$ may be partially or fully neutralized to form bisulfate $\left(\mathrm{HSO}_{4}{ }^{2-}\right)$ or sulfate $\left(\mathrm{SO}_{4}{ }^{2-}\right)$ salts and $\mathrm{NH}_{3}$ may also react with $\mathrm{HNO}_{3}$ to form $\mathrm{NH}_{4} \mathrm{NO}_{3}$. As a semi-volatile compound, the formation of $\mathrm{NH}_{4} \mathrm{NO}_{3}$ is also impacted by the ambient condition such as temperature (T) and relative humidity (RH); low $\mathrm{T}$ and high $\mathrm{RH}$ tend to favor the formation of $\mathrm{NH}_{4} \mathrm{NO}_{3}$ [22-24].

Studies on the formation of the $\mathrm{PPM}_{2.5}$ as impacted by the changes in the concentrations of precursor gases have been carried out through modeling approaches [25-27]. ISORROPIA II is a commonly used thermodynamic equilibrium model to simulate the dynamics of phase changes (e.g., gas, liquid, and solid) and interaction of different chemical species including $\mathrm{NH}_{4}{ }^{+}$, nitrate $\left(\mathrm{NO}_{3}{ }^{-}\right), \mathrm{SO}_{4}{ }^{2-}$, chloride $\left(\mathrm{Cl}^{-}\right)$, potassium $\left(\mathrm{K}^{+}\right)$, calcium $\left(\mathrm{Ca}^{2+}\right)$, magnesium $\left(\mathrm{Mg}^{2+}\right)$, and sodium $\left(\mathrm{Na}^{+}\right)$in ambient air [26,28]. This model simulates the gas-particle partitioning phenomenon and impacts of $\mathrm{T}$ and $\mathrm{RH}$ on such partitioning [29-32]. The relationship of $\mathrm{iPM}_{2.5}$ and its precursor gases at an agricultural site located in eastern North Carolina (NC) was studied using field measurements and ISORROPIA model simulation [33]. The research examined the impacts of the $50 \%$ reduction in total $\mathrm{NH}_{3}$ (gas + aerosol), total $\mathrm{HNO}_{3}$ (gas + aerosol), and total $\mathrm{H}_{2} \mathrm{SO}_{4}$ (aerosol) concentrations on the changes in $\mathrm{iPM}_{2.5}$ concentrations in winter and summer. It was found that the $50 \%$ reduction in total $\mathrm{NH}_{3}$ concentration may not lead to a significant reduction in $\mathrm{iPM}_{2.5}$ concentration. This may suggest that $\mathrm{NH}_{3}$ emissions from Animal Feeding Operations (AFOs) at agricultural sites led to elevated atmospheric $\mathrm{NH}_{3}$ concentration and $\mathrm{NH}_{3}$-rich conditions dominated; thus, the change in $\mathrm{iPM}_{2.5}$ concentration was not sensitive to the change in $\mathrm{NH}_{3}$ concentrations. To understand the formation of $\mathrm{iPM}_{2.5}$ as impacted by AFOs $\mathrm{NH}_{3}$ emissions, the response of $\mathrm{iPM}_{2.5}$ to $\mathrm{NH}_{3}$ concentrations near an egg production farm in the southeastern U.S. was studied [34]. The $\mathrm{NH}_{3}$ concentrations and $\mathrm{iPM}_{2.5}$ chemical compositions measured at in-house and ambient locations were used as inputs in ISORROPIA II model to simulate the responses of $\mathrm{iPM}_{2.5}$ to the concentrations of precursor gases, $\mathrm{T}$, and $\mathrm{RH}$. It was confirmed that the most significant reduction in $\mathrm{iPM}_{2.5}$ could be achieved by the reduction in total $\mathrm{H}_{2} \mathrm{SO}_{4}$ instead of total $\mathrm{NH}_{3}$. It was also suggested that in $\mathrm{NH}_{3}$-rich areas, $\mathrm{NH}_{3}$ was in excess to neutralize the acidic gases and the formation of the $\mathrm{iPM}_{2.5}$ was limited by the availability of acidic gases [34]. The changes in the partitioning of $\mathrm{NH}_{3}-\mathrm{NH}_{4}{ }^{+}$ caused by the changes in precursor gases may vary under different ambient conditions in response to the unique atmospheric chemical conditions and local meteorology; thus, more efforts are needed to investigate the partitioning of $\mathrm{NH}_{3}-\mathrm{NH}_{4}{ }^{+}$[35-37].

The effects of changes in total $\mathrm{H}_{2} \mathrm{SO}_{4}$ (aerosol), total $\mathrm{NH}_{3}$ (gas + aerosol), and total $\mathrm{HNO}_{3}$ (gas + aerosol) on i $\mathrm{PM}_{2.5}$ concentrations have been studied in the southeastern U.S. from 1998 to 2004 under the Southeastern Aerosol Research and Characterization (SEARCH) network. It was reported that the formation of $\mathrm{NO}_{3}{ }^{-}$was limited by the availability of $\mathrm{NH}_{3}$ in 1998-1999 [38]. Another study also indicated that the combination of the reductions in total $\mathrm{H}_{2} \mathrm{SO}_{4}$ and total $\mathrm{HNO}_{3}$ was more effective to decrease i $\mathrm{PM}_{2.5}$ mass concentration in 1998-2001 [39]. Reduction in total $\mathrm{H}_{2} \mathrm{SO}_{4}$ was more effective in decreasing $\mathrm{iPM}_{2.5}$ concentrations in 2004 [40]. Formation of $\mathrm{PPM}_{2.5}$ was limited by the availability of $\mathrm{NH}_{3}$ in rural-forest and coastal areas of the southeastern U.S. in 2004 [41]. While the above research provides fundamental understanding of secondary iPM $\mathrm{P}_{2.5}$ formation, the implementations of new regulations [42-44] led to the temporal changes in precursor gases emissions in the southeastern U.S.; thus, the responses of $\mathrm{iPM}_{2.5}$ concentrations and partitioning of $\mathrm{NH}_{3}-\mathrm{NH}_{4}{ }^{+}$to the changes in total $\mathrm{H}_{2} \mathrm{SO}_{4}$, total $\mathrm{NH}_{3}$, and total $\mathrm{HNO}_{3}$ may also change over time [45]. The objective of this research is to investigate the partitioning of $\mathrm{NH}_{3}-\mathrm{NH}_{4}{ }^{+}$in urban and rural areas of the southeastern U.S. under different meteorological conditions using the latest field measurements of $\mathrm{iPM}_{2.5}$ and precursor gases. The research findings may provide further insights to develop effective $\mathrm{PM}_{2.5}$ control strategies. 


\section{Materials and Methods}

\subsection{Data Acquisition and Processing}

This research utilized the $24 \mathrm{~h}$ particle-phase measurements and $1 \mathrm{~h}$ average gasphase measurements from the SEARCH network [46] (Figure 1). For $24 \mathrm{~h}$ measurements, the chemical compositions of $\mathrm{PM}_{2.5}$ were measured using filter-based Federal Reference Method (FRM), and $1 \mathrm{~h}$ average measurements were converted from $1 \mathrm{~min}$ or $5 \mathrm{~min}$ continuous measurements (Table S1); the detailed information about measurement techniques and detection limits can be found in SEARCH network literature [46]. The $\mathrm{NH}_{3}$ gas concentration measurements were available at five sites named YRK, JST, CTR, BHM, and OLF in 2012-2016; thus, the responses of the partitioning of $\mathrm{NH}_{3}-\mathrm{NH}_{4}{ }^{+}$to the changes in precursor gases were investigated at these five sites. The dataset includes some $\mathrm{NH}_{3}$ values that are either negative or below the detection limit. The negative values were excluded from data analysis, while the values below the detection limit were replaced with half of the detection limit $[47,48]$.

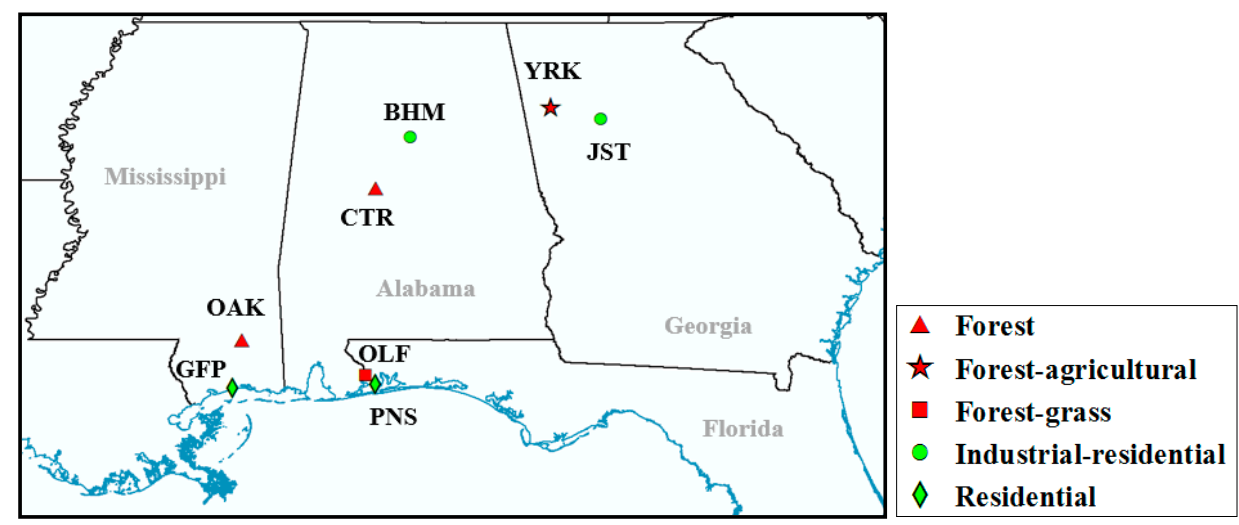

Figure 1. The geographical locations of the eight monitoring sites of the SEARCH network [46].

\subsection{Investigation of the Partitioning of $\mathrm{NH}_{3}-\mathrm{NH}_{4}{ }^{+}$}

The partitioning of $\mathrm{NH}_{3}-\mathrm{NH}_{4}{ }^{+}$was investigated using ISORROPIA II [27]. The model performance evaluation was performed in another study; thus, it will not be further elaborated on. In this research, $10 \%$ to $90 \%$ reductions in total $\mathrm{NH}_{3}$, total $\mathrm{H}_{2} \mathrm{SO}_{4}$, and total $\mathrm{HNO}_{3}$ at the five sites in four seasons were used to investigate the responses of $\mathrm{iPM}_{2.5}\left(\mathrm{NH}_{4}{ }^{+}+\mathrm{NO}_{3}{ }^{-}+\mathrm{SO}_{4}{ }^{2-}\right)$ to the changes in precursor gases in 2012-2016, spring and fall results are the transition case scenarios between summer and winter; thus, only summer and winter results are reported and discussed here. Moreover, only the gas-particle partitioning processes are considered, other processes such as emissions, dispersion, and dry and wet depositions are thus not included in this research.

The concentrations of $\mathrm{iPM}_{2.5}$ and $\mathrm{NH}_{4}{ }^{+}$under different total $\mathrm{NH}_{3}$, total $\mathrm{H}_{2} \mathrm{SO}_{4}$, and total $\mathrm{HNO}_{3}$ concentrations in four seasons were simulated using $24 \mathrm{~h}$ average data at the five sites. The gas-phase $\mathrm{NH}_{3}$ molar fraction $\left(\mathrm{NH}_{3} / \mathrm{NH}_{\mathrm{x}}\right)$ in Equation $(1)[49,50]$ was used to study the effects of changes in precursor gases on the partitioning of $\mathrm{NH}_{3}-\mathrm{NH}_{4}{ }^{+}$.

$$
\mathrm{NH}_{3} / \mathrm{NH}_{\mathrm{x}}=\left[\mathrm{NH}_{3}\right] /\left(\left[\mathrm{NH}_{3}\right]+\left[\mathrm{NH}_{4}^{+}\right]\right)
$$

Gas ratio (GR) in Equation (2) [25,51] was calculated to study the effects of changes in precursor gases concentrations on the atmospheric chemical conditions, diurnal variation of $i \mathrm{PM}_{2.5}$ and partitioning of $\mathrm{NH}_{3}-\mathrm{NH}_{4}{ }^{+}$.

$$
\mathrm{GR}=([\mathrm{TA}]-2 \times[\mathrm{TS}]) /[\mathrm{TN}]
$$

where [TA] is the sum of molar concentrations of $\mathrm{NH}_{3}$ and ammonium $\left(\mathrm{NH}_{4}^{+}\right)$(in the unit of $\left.\mu \mathrm{mol} \mathrm{m}{ }^{-3}\right)$; [TS] is the sum of molar concentrations of $\mathrm{SO}_{4}{ }^{2-}$, bisulfate $\left(\mathrm{HSO}_{4}{ }^{-}\right)$, and 
$\mathrm{H}_{2} \mathrm{SO}_{4}$ (in the unit of $\mu \mathrm{mol} \mathrm{m}{ }^{-3}$ ); and [TN] is the sum of molar concentrations of $\mathrm{HNO}_{3}$ and nitrate $\left(\mathrm{NO}_{3}{ }^{-}\right)$(in the unit of $\mu \mathrm{mol} \mathrm{m}{ }^{-3}$ ).

The $\mathrm{pH}$ [52] was calculated to study the acidity of the inorganic aerosol.

$$
\mathrm{pH}=-\log _{10} \frac{1000 \gamma_{\mathrm{H}^{+}} \mathrm{H}_{\text {air }}^{+}}{\mathrm{W}}
$$

where $\gamma_{\mathrm{H}}{ }^{+}$is the hydronium ion activity coefficient, which is set as unity; $\mathrm{H}_{\text {air }}{ }^{+}\left(\mu \mathrm{g} \mathrm{m}{ }^{-3}\right)$ is the hydronium ion concentration in volume of air; and $\mathrm{W}\left(\mu \mathrm{g} \mathrm{m}^{-3}\right)$ is particle water concentration associated with inorganic aerosol. Both $\mathrm{H}_{\text {air }}{ }^{+}$and $\mathrm{W}$ are from ISORROPIA II model output.

\subsection{ISORROPIA II Model}

The performance of ISORROPIA II for predicting inorganic aerosols in the southeastern U.S. was investigated in another research [53] and the ISORROPIA II model predicted the concentrations of various compositions of $\mathrm{PPM}_{2.5}$ well.

For this study, the $\mathrm{PPM}_{2.5}$ was assumed to be internally mixed, and the thermodynamic equilibrium was also assumed to be established instantaneously [29]. The ISORROPIA II allows the user to specify the problem type (forward or reverse) and thermodynamic state (stable or metastable). In this study, ISORROPIA II is set as forward type, which requires the concentrations of total $\mathrm{NH}_{3}$ (gas + aerosol), total $\mathrm{HNO}_{3}$ (gas + aerosol), and total $\mathrm{H}_{2} \mathrm{SO}_{4}$ (aerosol) as the model input. The metastable thermodynamic state was selected in this research [15,32].

\subsection{Multiple Linear Regression Model}

The multiple linear regression (MLR) model was constructed to examine the response of $\mathrm{NH}_{4}{ }^{+}$to various factors. Step-wise model selection method based on the Bayesian information criterion (BIC) was used to select the best fitting model from Equation (4):

$$
\mathrm{NH}_{4}{ }^{+}=\beta_{0}+\beta_{\mathrm{i}} \times \mathrm{x}_{\mathrm{i}}+\text { interaction terms }+ \text { quadratic terms }+\varepsilon_{\mathrm{i}}
$$

where $\mathrm{x}_{\mathrm{i}}$ are $\mathrm{iPM}_{2.5}$ chemical components and gaseous pollutants including $\mathrm{SO}_{4}{ }^{2-}, \mathrm{NO}_{3}{ }^{-}$, $\mathrm{Ca}^{2+}, \mathrm{Mg}^{2+}, \mathrm{K}^{+}, \mathrm{Na}^{+}, \mathrm{Cl}^{-}, \mathrm{NH}_{3}$, and $\mathrm{HNO}_{3}$, ambient $\mathrm{T}$, and $\mathrm{RH}$. Interaction terms include up to two factors. All the gas- and particle-phase pollutants were converted in the unit of $\mu \mathrm{g} \mathrm{m}^{-3}$, $\mathrm{T}$ was in ${ }^{\circ} \mathrm{C}, \mathrm{RH}$ was in $\%$. The $24 \mathrm{~h}$ average $\mathrm{Cl}^{-}, \mathrm{K}^{+}, \mathrm{Na}^{+}, \mathrm{Mg}^{2+}, \mathrm{Ca}^{2+}, \mathrm{NH}_{4}{ }^{+}$, $\mathrm{SO}_{4}{ }^{2-}$, and $\mathrm{NO}_{3}{ }^{-}$data and $1 \mathrm{~h}$ average $\mathrm{T}, \mathrm{RH}, \mathrm{NH}_{3}$, and $\mathrm{HNO}_{3}$ data were available at the BHM site (2011-2016), CTR site (2012-2016), JST site (2010-2016), YRK site (2008-2016), OLF site (2013-2016), and OAK site (2010). The MLR model was built in two periods: 2008-2011 and 2012-2016. The best fitting MLR models vary in space and time and are only used to aid in the investigation of partitioning of $\mathrm{NH}_{3}-\mathrm{NH}_{4}{ }^{+}$.

\section{Results and Discussion}

\subsection{Statistical Characterization of the Field Measurement Data}

The statistical summaries of $\mathrm{iPM}_{2.5}$ precursor gases, nonvolatile cations (NVCs), $\mathrm{T}$ and RH at six sites in two periods (2008-2011 and 2012-2016) are shown in Tables S2-S10. Tables S2-S10 reveal the seasonal variations of different precursor gases such as $\mathrm{H}_{2} \mathrm{SO}_{4}$, $\mathrm{HNO}_{3}, \mathrm{HCl}, \mathrm{NH}_{3}$, and NVCs such as $\mathrm{Na}^{+}, \mathrm{K}^{+}, \mathrm{Mg}^{2+}$, and $\mathrm{Ca}^{2+}$ as well as $\mathrm{T}$ and $\mathrm{RH}$ at the six sites of the SEARCH network. In general, $\mathrm{T}$ and $\mathrm{RH}$ were both lowest in winter and highest in summer (see the Supplementary Materials). The concentration of total $\mathrm{H}_{2} \mathrm{SO}_{4}$ was higher in summer than the other seasons at the six sites. The concentrations of total $\mathrm{NH}_{3}$ and total $\mathrm{HNO}_{3}$ did not exhibit a distinct seasonal pattern, which may be caused by spatial variation of emissions sources at the six sites of the southeastern U.S.

The concentrations of $\mathrm{iPM}_{2.5}$ chemical compositions and precursor gases were also measured in different locations of the world. The aerosol composition measurements and source apportionment studies in a coastal city of eastern China during 2018-2019 
indicated that inorganic aerosols accounted for a large portion of $\mathrm{PM}_{2.5}$ mass concentration and local steel plant emissions were dominated by $\left.\mathrm{NH}_{4}\right)_{2} \mathrm{SO}_{4}$ and ammonium bisulfate $\left(\mathrm{NH}_{4} \mathrm{HSO}_{4}\right)$; in addition, the $\mathrm{PPM}_{2.5}$ concentrations at the coastal city of China were much higher than that measured in the southeastern U.S. [54]. The inorganic composition of $\mathrm{PM}_{2.5}$ and precursor gases were measured at Seoul and Deokjeok Island of South Korea in 2014, where the haze aerosols mainly consisted of inorganics (e.g., $\mathrm{NH}_{4}{ }^{+}$salts); ISORROPIA II model simulations implicated that the addition of $\mathrm{SO}_{4}{ }^{2-}$ into the aerosols during the transport process increased the mass concentrations of $\mathrm{NH}_{4} \mathrm{NO}_{3}$, and another finding is that the concentrations of total $\mathrm{NH}_{3}$, total $\mathrm{HNO}_{3}$, and total $\mathrm{H}_{2} \mathrm{SO}_{4}$ were also higher than the measurement values in the southeastern U.S. during the same period of time [55]. Moreover, a newly developed method was used in Brno, Czech in 2018, to simultaneously measure the concentrations of gaseous $\mathrm{NH}_{3}$ and aerosol $\mathrm{NH}_{4}{ }^{+}$with a time resolution of $1 \mathrm{~s}$; the measurement results indicated a seasonal variation for $\mathrm{NH}_{3}$ and $\mathrm{NH}_{4}{ }^{+}$with higher $\mathrm{NH}_{3}$ concentrations in summer, and higher $\mathrm{NH}_{4}{ }^{+}$concentrations in winter; the ratio of $\mathrm{NH}_{3} / \mathrm{NH}_{4}{ }^{+}$indicated the dominance of $\mathrm{NH}_{3}$ and $\mathrm{NH}_{4}{ }^{+}$in summer and winter, respectively [56]. The difference in local to regional emissions sources contributed to the spatial and temporal variations of iPM 2.5 and partitioning of $\mathrm{NH}_{3}-\mathrm{NH}_{4}{ }^{+}$across the world.

\subsection{Seasonal Simulation of Partitioning of $\mathrm{NH}_{3}-\mathrm{NH}_{4}{ }^{+}$}

The responses of iPM $\mathrm{PM}_{2.5}, \mathrm{NH}_{4}{ }^{+}$, and $\mathrm{NH}_{3} / \mathrm{NH}_{\mathrm{x}}$ to the changes in total $\mathrm{NH}_{3}$ and total $\mathrm{HNO}_{3}$ in 2012-2016 are presented in Figure 2 and Figures S1-S4.
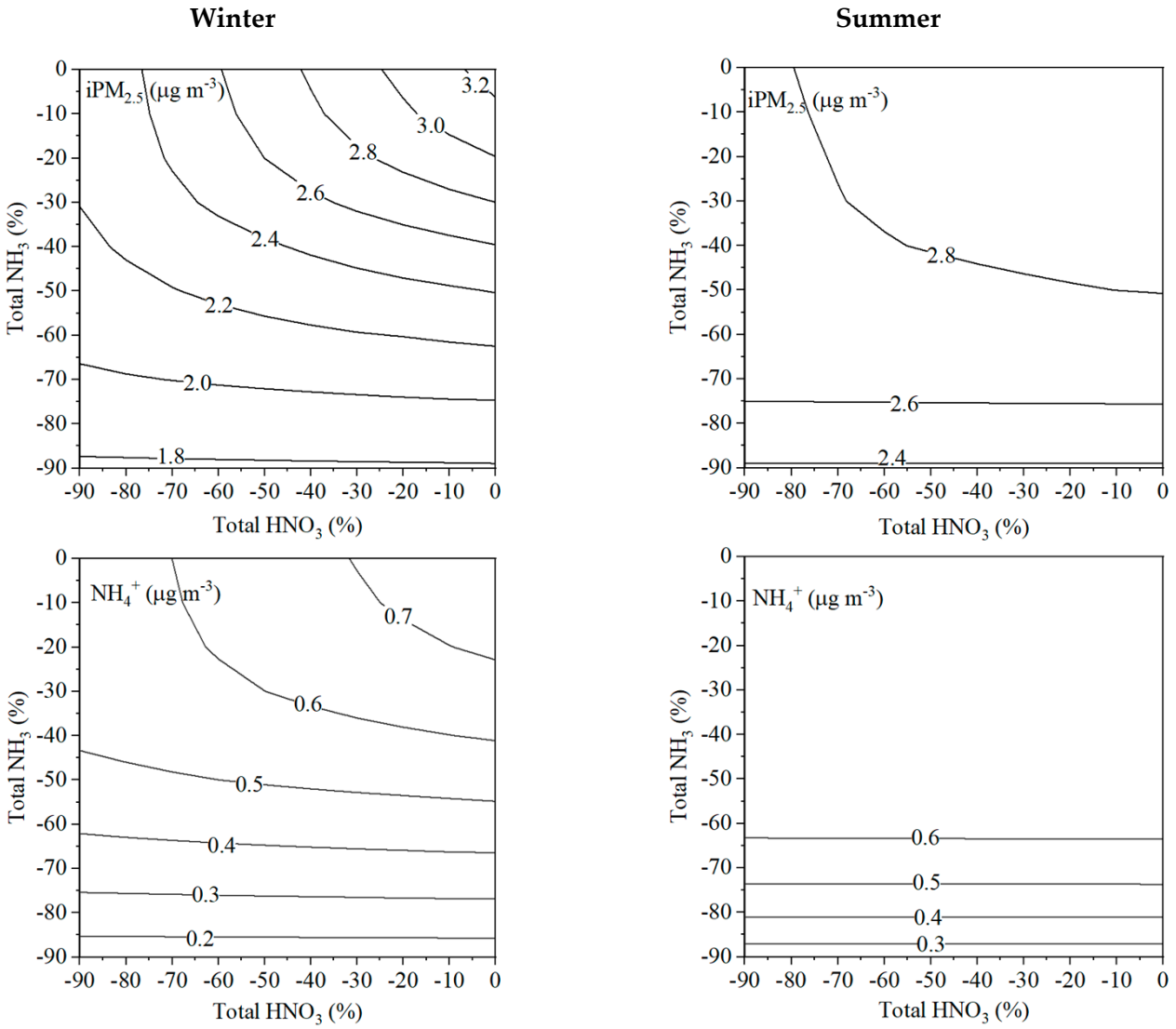

Figure 2. Cont. 

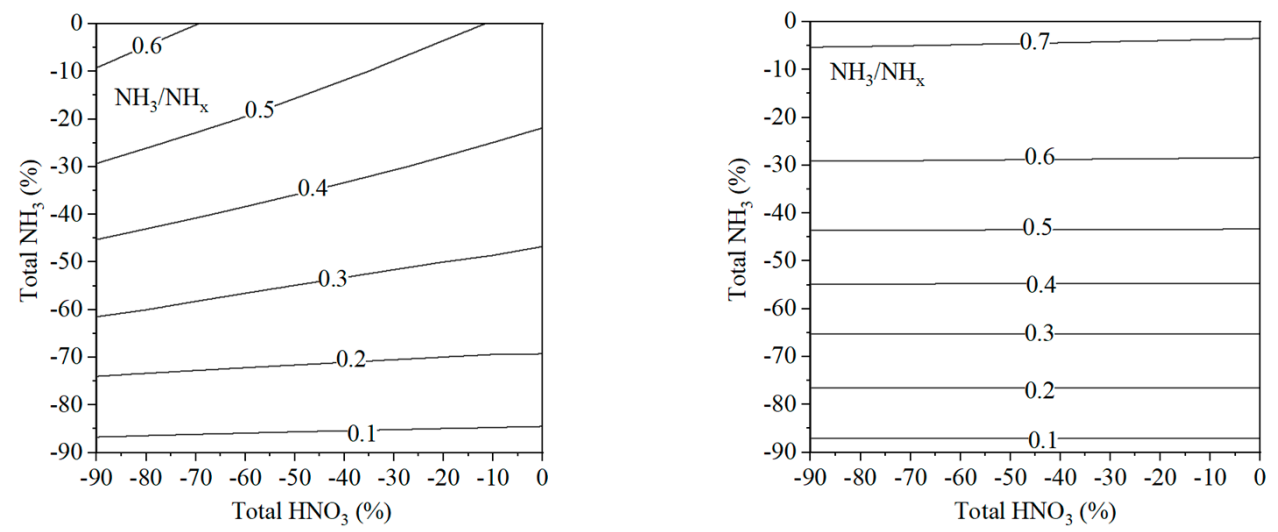

Figure 2. Responses of $\mathrm{iPM}_{2.5}, \mathrm{NH}_{4}{ }^{+}$, and $\mathrm{NH}_{3} / \mathrm{NH}_{\mathrm{X}}$ to the changes in $\mathrm{TNH}_{3}$ and $\mathrm{THNO}_{3}$ at the YRK site in summer and winter of 2012-2016, the average total $\mathrm{NH}_{3}$ concentrations were reduced from $1.53 \mu \mathrm{g} \mathrm{m}^{-3}$ ( $0 \%$ reduction) to $0.153 \mu \mathrm{g} \mathrm{m}^{-3}$ (90\% reduction) and from $2.66 \mu \mathrm{g} \mathrm{m}^{-3}$ ( $0 \%$ reduction) to $0.266 \mu \mathrm{g} \mathrm{m}^{-3}$ (90\% reduction) in winter and summer, respectively; the average total $\mathrm{HNO}_{3}$ concentrations were reduced from $1.41 \mathrm{\mu g} \mathrm{m}^{-3}$ ( $0 \%$ reduction) to $0.141 \mathrm{\mu g} \mathrm{m}^{-3}$ (90\% reduction) and from $1.11 \mu \mathrm{g} \mathrm{m}^{-3}$ ( $0 \%$ reduction) to 0.111 (90\% reduction) in winter and summer, respectively.

As can be seen in Figures 2 and S1-S4, the formation of $\mathrm{iPM}_{2.5}$ and the partitioning of $\mathrm{NH}_{3}-\mathrm{NH}_{4}{ }^{+}$were sensitive to the changes in total $\mathrm{NH}_{3}$ concentration when total $\mathrm{NH}_{3}$ concentration was reduced at least $20 \%$ or when total $\mathrm{HNO}_{3}$ concentration was not reduced in 2012-2016. Although the YRK, JST, BHM, and OLF sites were all under $\mathrm{NH}_{3}$-rich condition, the $\mathrm{pH}$ analysis indicated that inorganic aerosols were still acidic (Table S11) instead of full neutralization. The reduction in total $\mathrm{NH}_{3}$ concentration could decrease the gas-phase $\mathrm{NH}_{3}$ concentration but could not decrease the formation of $\mathrm{PPM}_{2.5}$. When enough reduction in total $\mathrm{NH}_{3}$ was achieved or acidic gases (total $\mathrm{H}_{2} \mathrm{SO}_{4}$ and total $\mathrm{HNO}_{3}$ ) were in excess to react with $\mathrm{NH}_{3}$ gas, the subsequent reduction in total $\mathrm{NH}_{3}$ can lead to the decrease in $\mathrm{iPM}_{2.5}$.

The formation of $\mathrm{PMM}_{2.5}$ and the partitioning of $\mathrm{NH}_{3}-\mathrm{NH}_{4}{ }^{+}$were more sensitive to the changes in total $\mathrm{NH}_{3}$ and total $\mathrm{HNO}_{3}$ in winter than in the other seasons. The semi-volatile characteristics of $\mathrm{NH}_{4} \mathrm{NO}_{3}$ may explain the seasonal variation of the responses of $\mathrm{iPM}_{2.5}$ to the change in total $\mathrm{NH}_{3}$ and total $\mathrm{HNO}_{3}$. The lower $\mathrm{T}$ in winter favored the formation of $\mathrm{NH}_{4} \mathrm{NO}_{3}$; if there was adequate $\mathrm{NH}_{3}$ reacting with acidic gases, then most of the $\mathrm{HNO}_{3}$ stayed in particle-phase [22,57]. Thus, as observed in Figures 2 and S1-S4, the formation of $\mathrm{iPM}_{2.5}$ was sensitive to the change in total $\mathrm{HNO}_{3}$ when total $\mathrm{NH}_{3}$ was not reduced in winter of 2012-2016.

The responses of iPM $\mathrm{PM}_{2.5}, \mathrm{NH}_{4}{ }^{+}$, and $\mathrm{NH}_{3} / \mathrm{NH}_{\mathrm{x}}$ to the changes in total $\mathrm{NH}_{3}$ and total $\mathrm{H}_{2} \mathrm{SO}_{4}$ are presented in Figures 3 and S5-S8.


Figure 3. Cont. 

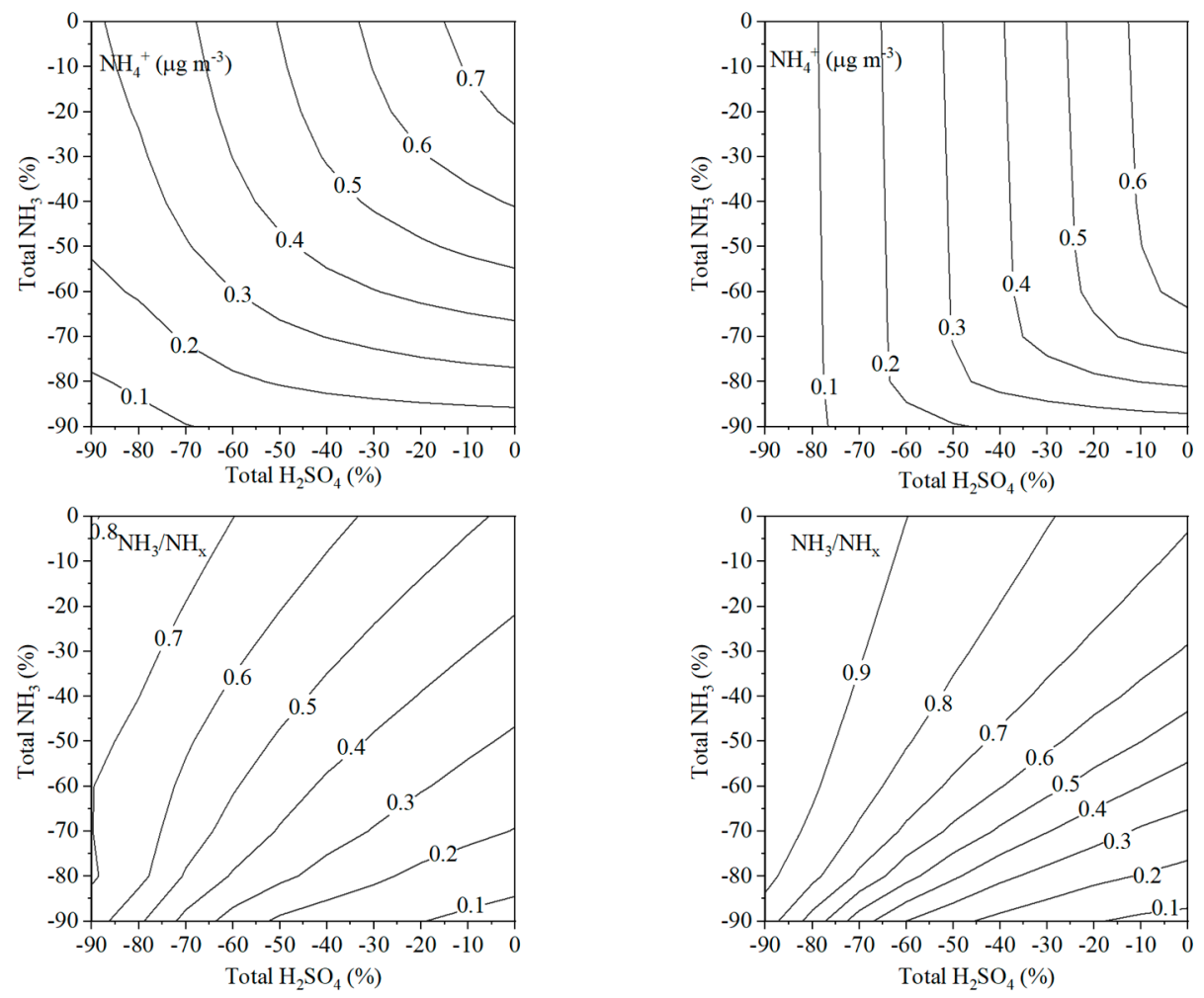

Figure 3. Responses of $\mathrm{PM}_{2.5}, \mathrm{NH}_{4}{ }^{+}$, and $\mathrm{NH}_{3} / \mathrm{NH}_{\mathrm{x}}$ to the changes in $\mathrm{TNH}_{3}$ and $\mathrm{TH}_{2} \mathrm{SO}_{4}$ at the YRK site in summer and winter of 2012-2016, the average total $\mathrm{NH}_{3}$ concentrations were reduced from $1.53 \mu \mathrm{g} \mathrm{m}^{-3}$ ( $0 \%$ reduction) to $0.153 \mu \mathrm{g} \mathrm{m}^{-3}$ (90\% reduction) and from $2.66 \mu \mathrm{g} \mathrm{m}^{-3}$ ( $0 \%$ reduction) to $0.266 \mu \mathrm{g} \mathrm{m}^{-3}$ (90\% reduction) in winter and summer, respectively; the average total $\mathrm{H}_{2} \mathrm{SO}_{4}$ concentrations were reduced from $1.56 \mu \mathrm{g} \mathrm{m}^{-3}\left(0 \%\right.$ reduction) to $0.156 \mu \mathrm{g} \mathrm{m}^{-3}$ (90\% reduction) and from $2.05 \mu \mathrm{g} \mathrm{m}^{-3}$ ( $0 \%$ reduction) to 0.205 (90\% reduction) in winter and summer, respectively.

As can be seen in Figures 3 and S5-S8, the formation of $\mathrm{PPM}_{2.5}$ was very sensitive to the change in total $\mathrm{H}_{2} \mathrm{SO}_{4}$ concentration in summer and winter. The reduction in total $\mathrm{H}_{2} \mathrm{SO}_{4}$ can effectively decrease the concentration of $\mathrm{iPM}_{2.5}$, and more $\mathrm{NH}_{3}$ stayed in the gas-phase in this process. The responses of $\mathrm{NH}_{4}{ }^{+}$to the change in total $\mathrm{H}_{2} \mathrm{SO}_{4}$ may exhibit two different regions. The less reduction in total $\mathrm{NH}_{3}$ and the more reduction in total $\mathrm{H}_{2} \mathrm{SO}_{4}$ were achieved, the more sensitive the $\mathrm{NH}_{4}{ }^{+}$responded to the change in total $\mathrm{H}_{2} \mathrm{SO}_{4}$. This can be explained that when $\mathrm{NH}_{3}$ was not adequate to react with both $\mathrm{HNO}_{3}$ and $\mathrm{H}_{2} \mathrm{SO}_{4}$, the reduction in $\mathrm{H}_{2} \mathrm{SO}_{4}$ may free some $\mathrm{NH}_{3}$ associated with $\mathrm{SO}_{4}{ }^{2-}$, and the available $\mathrm{NH}_{3}$ can react with $\mathrm{HNO}_{3}$ to form $\mathrm{NH}_{4} \mathrm{NO}_{3}$, which lead to the decrease in $\mathrm{SO}_{4}{ }^{2-}$ salts and increase in $\mathrm{NO}_{3}{ }^{-}$salts. Thus, $\mathrm{NH}_{4}{ }^{+}$concentration may remain at approximately the same level. Furthermore, when greater than $80 \%$ reduction in total $\mathrm{H}_{2} \mathrm{SO}_{4}$ was achieved, the reduction in total $\mathrm{H}_{2} \mathrm{SO}_{4}$ may lead to the increase in $\mathrm{iPM}_{2.5}$ at the JST (Figure S5), CTR (Figure S6), and OLF (Figure S8) sites in winter.

The formation of $\mathrm{iPM}_{2.5}$ was more sensitive to the change in total $\mathrm{H}_{2} \mathrm{SO}_{4}$ in summer than in winter. This can be explained by the dominance of $\mathrm{SO}_{4}{ }^{2-}$ salts in $\mathrm{iPM}_{2.5}$ in summer. The more intense summer solar radiation enhanced the transformation of $\mathrm{SO}_{2}$ to $\mathrm{SO}_{4}{ }^{2-}$ [24]. Moreover, as the high $\mathrm{T}$ in summer did not facilitate the formation of $\mathrm{NH}_{4} \mathrm{NO}_{3}$, the decrease in $\mathrm{SO}_{4}{ }^{2-}$ salts caused by the reduction in total $\mathrm{H}_{2} \mathrm{SO}_{4}$ will not be offset by the increase in the $\mathrm{NO}_{3}{ }^{-}$salts.

\subsection{Diurnal Simulation of the Partitioning of $\mathrm{NH}_{3}-\mathrm{NH}_{4}{ }^{+}$}

In addition to the investigation of the partitioning of $\mathrm{NH}_{3}-\mathrm{NH}_{4}{ }^{+}$in four seasons, the partitioning of $\mathrm{NH}_{3}-\mathrm{NH}_{4}{ }^{+}$was also studied in different time of the day at the five sites in 
2012-2016, the results of YRK site are shown in Figures 4-6, the results at the other sites are shown in Figures S9-S20.

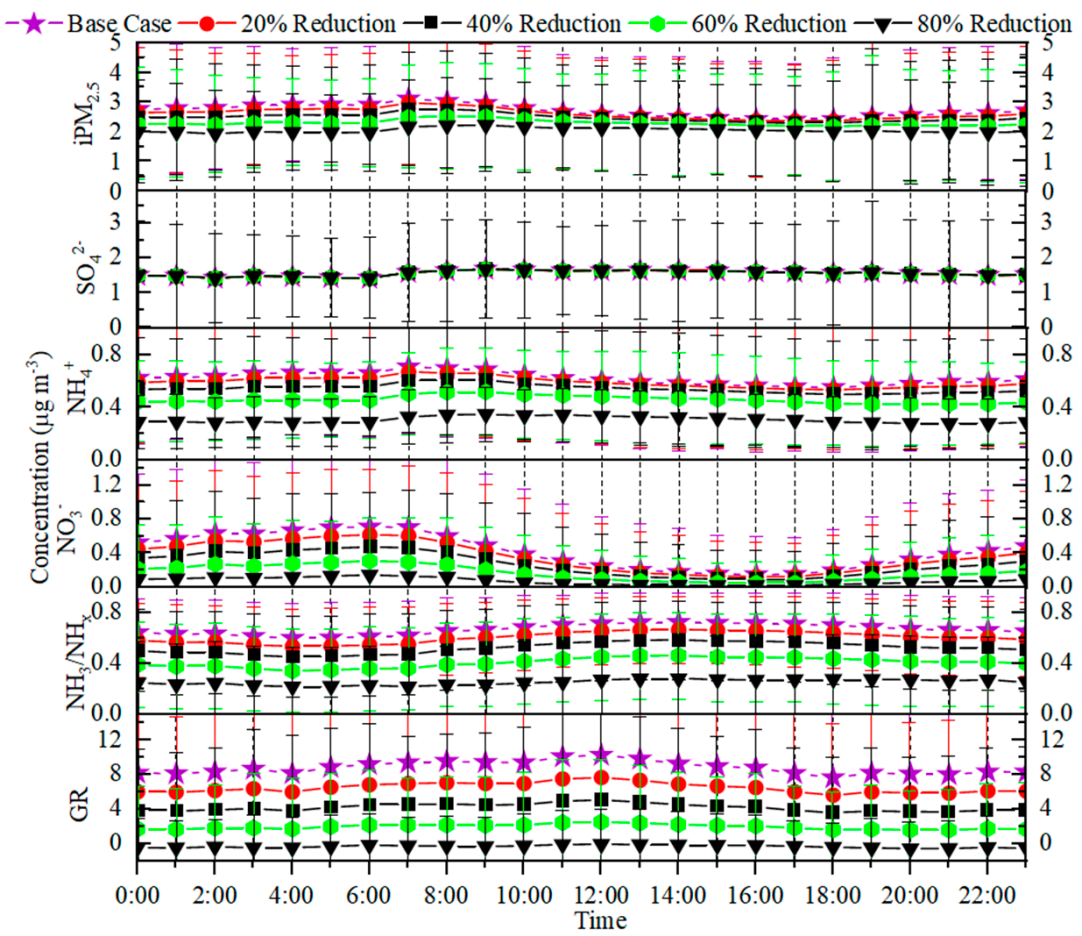

Figure 4. Responses of $\mathrm{iPM}_{2.5}, \mathrm{SO}_{4}{ }^{2-}, \mathrm{NH}_{4}{ }^{+}, \mathrm{NO}_{3}{ }^{-}, \mathrm{NH}_{3} / \mathrm{NH}_{\mathrm{x}}$, and GR to the reductions in $\mathrm{TNH}_{3}$ at the YRK site in 2012-2016.

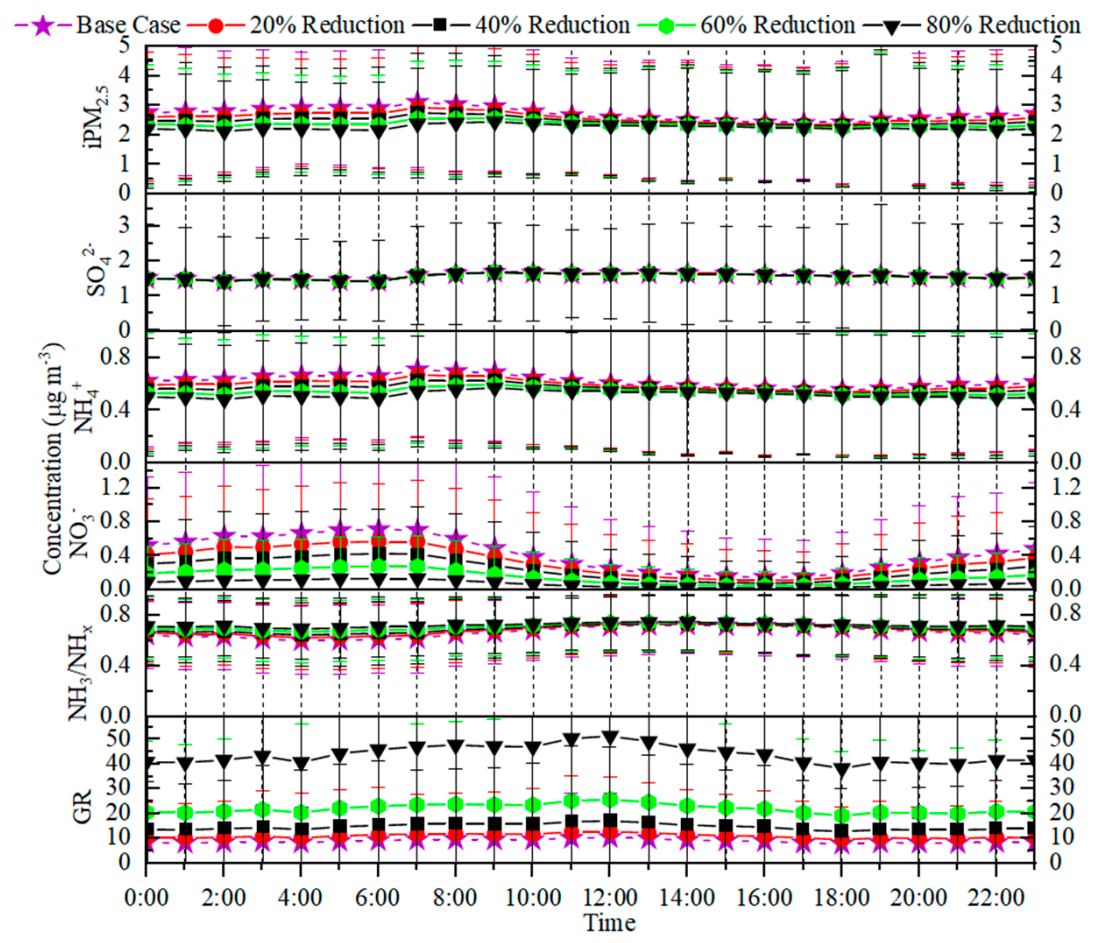

Figure 5. Responses of $\mathrm{PPM}_{2.5}, \mathrm{SO}_{4}{ }^{2-}, \mathrm{NH}_{4}{ }^{+}, \mathrm{NO}_{3}{ }^{-}, \mathrm{NH}_{3} / \mathrm{NH}_{\mathrm{x}}$, and GR to the reductions in $\mathrm{THNO}_{3}$ at the YRK site in 2012-2016. 


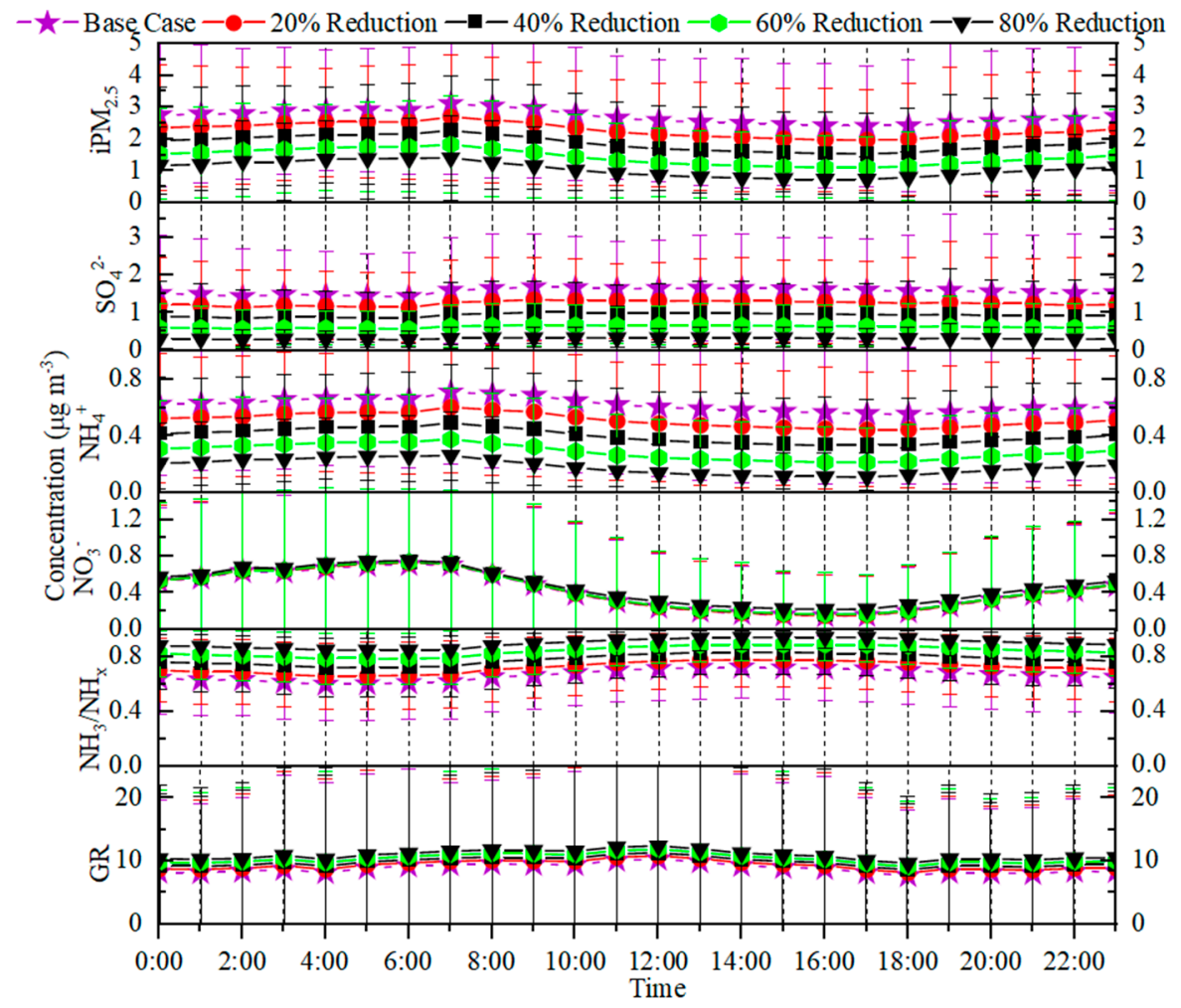

Figure 6. Responses of $\mathrm{iPM}_{2.5}, \mathrm{SO}_{4}{ }^{2-}, \mathrm{NH}_{4}{ }^{+}, \mathrm{NO}_{3}{ }^{-}, \mathrm{NH}_{3} / \mathrm{NH}_{\mathrm{x}}$, and GR to the reductions in $\mathrm{TH}_{2} \mathrm{SO}_{4}$ at the YRK site in 2012-2016.

Figures 4-6 indicate that the reduction in total $\mathrm{NH}_{3}$ and total $\mathrm{HNO}_{3}$ may not be effective in reducing the concentration of $\mathrm{iPM}_{2.5}$ unless more than a $60 \%$ reduction can be achieved. The reduction in total $\mathrm{NH}_{3}$ and total $\mathrm{HNO}_{3}$ can only lead to a decrease in $\mathrm{NH}_{4} \mathrm{NO}_{3}$, while the $\mathrm{SO}_{4}{ }^{2-}$ concentration remained at approximately the same level. The reduction in total $\mathrm{NH}_{3}$ concentration reduced both $\mathrm{NH}_{3} / \mathrm{NH}_{\mathrm{x}}$ and GR, and more $\mathrm{NH}_{3}$ partitioned towards particle-phase. The reduction in total $\mathrm{HNO}_{3}$ led to the increase in both $\mathrm{NH}_{3} / \mathrm{NH}_{\mathrm{x}}$ and $\mathrm{GR}$, and more $\mathrm{NH}_{3}$ remained in the gas-phase. Overall, Figures 4-6 illustrate that the reductions in total $\mathrm{NH}_{3}$ and total $\mathrm{HNO}_{3}$ are ineffective for controlling $\mathrm{iPM}_{2.5}$ concentration.

Figure 6 shows that the reduction in total $\mathrm{H}_{2} \mathrm{SO}_{4}$ was more effective in reducing the concentrations of $\mathrm{iPM}_{2.5}$; however, the reduction in total $\mathrm{H}_{2} \mathrm{SO}_{4}$ may lead to the increase in $\mathrm{NO}_{3}{ }^{-}$concentration, especially at the CTR and OLF sites (Figures S14 and S20) (e.g., at 12:00 p.m., $80 \%$ total $\mathrm{H}_{2} \mathrm{SO}_{4}$ reduction at the CTR site $\left(1.50 \rightarrow 0.30 \mu \mathrm{g} \mathrm{m}^{-3}\right)$ resulted in the decrease in $\mathrm{iPM}_{2.5}\left(2.11 \rightarrow 0.66 \mu \mathrm{g} \mathrm{m}^{-3}\right)$ and increase in $\left.\mathrm{NO}_{3}{ }^{-}\left(0.03 \rightarrow 0.16 \mu \mathrm{g} \mathrm{m}^{-3}\right)\right)$. The YRK, JST, and BHM sites were all in $\mathrm{NH}_{3}$-rich area, and the reduction in total $\mathrm{H}_{2} \mathrm{SO}_{4}$ may free some $\mathrm{NH}_{3}$ associated with $\mathrm{H}_{2} \mathrm{SO}_{4}$, however, the increase in gas-phase $\mathrm{NH}_{3}$ was not able to transform more $\mathrm{HNO}_{3}$ into particle-phase at $\mathrm{NH}_{3}$-rich sites (Figure 6, Figures $\mathrm{S} 11$ and $\mathrm{S17}$ ). While at the CTR and OLF sites (Figures S14 and S20), the increase in gas-phase $\mathrm{NH}_{3}$ may change the partitioning of $\mathrm{HNO}_{3}-\mathrm{NO}_{3}{ }^{-}$toward particle-phase when the $\mathrm{NH}_{3}$ is not in excess to neutralize both $\mathrm{HNO}_{3}$ and $\mathrm{H}_{2} \mathrm{SO}_{4}$. The reduction in total $\mathrm{H}_{2} \mathrm{SO}_{4}$ can also increase both $\mathrm{NH}_{3} / \mathrm{NH}_{\mathrm{x}}$ and $\mathrm{GR}$, which indicates that more $\mathrm{NH}_{3}$ stayed in the gas-phase rather than in the particle-phase in this process.

Reduction in total $\mathrm{H}_{2} \mathrm{SO}_{4}$ concentration may lead to a significant reduction in $\mathrm{iPM}_{2.5}$; thus, it was more effective than reducing total $\mathrm{HNO}_{3}$ and total $\mathrm{NH}_{3}$ concentrations to reduce i $\mathrm{PM}_{2.5}$ concentration. However, the reduction in total $\mathrm{H}_{2} \mathrm{SO}_{4}$ concentration may also increase the concentration $\mathrm{NO}_{3}{ }^{-}$at the CTR and OLF sites (Figures S14 and S20). Thus, the future reduction in $\mathrm{PPM}_{2.5}$ may necessitate the coordinated reduction in both $\mathrm{H}_{2} \mathrm{SO}_{4}$ and $\mathrm{HNO}_{3}$ in the southeastern U.S. 
The YRK site was located in a rural area impacted by the $\mathrm{NH}_{3}$ emissions from AFOs, while BHM and JST sites were located in the area impacted by industrial emission sources. The CTR site was located in a forest area and the OLF site was located in a suburban area. The spatial variation of the responses of the partitioning of $\mathrm{NH}_{3}-\mathrm{NH}_{4}{ }^{+}$to the reductions in precursor gases implicated the important impact of $\mathrm{AFOs} \mathrm{NH}_{3}$ emissions. At the agricultural rural site-YRK site, the $\mathrm{NH}_{3}$ emissions from AFOs led to elevated $\mathrm{NH}_{3}$ concentration, which was in excess to neutralize acidic gases, and the formation of $\mathrm{NH}_{4} \mathrm{NO}_{3}$ was not affected by the reduction in total $\mathrm{H}_{2} \mathrm{SO}_{4}$ [36].

\subsection{Multiple Linear Regression Model}

The effects of the various predictor variables (e.g., $\mathrm{SO}_{4}{ }^{2-}, \mathrm{NO}_{3}{ }^{-}, \mathrm{NH}_{3}$, etc.) on the response variable $\left(\mathrm{NH}_{4}{ }^{+}\right)$were estimated using regression analysis. The MLR models for the responses of $\mathrm{NH}_{4}{ }^{+}$to various factors in two periods (2008-2011 and 2012-2016) at the six sites were shown in Tables 1,2 and S12-S18.

Table 1. The summary of final MLR model coefficients at the YRK site from 2008 to 2011.

\begin{tabular}{ccccc}
\hline Predictors & Coefficients & SE & t Value & Pr $>|\mathbf{t}|$ \\
\hline Intercept $\left(\beta_{0}\right)$ & 0.08 & 0.033 & 2.39 & 0.018 \\
$\mathrm{SO}_{4}{ }^{-}\left(\beta_{1}\right)$ & 0.33 & 0.009 & 37.11 & $<2 \times 10^{-16}$ \\
$\mathrm{NO}_{3}{ }^{-}\left(\beta_{2}\right)$ & 0.25 & 0.018 & 13.64 & $<2 \times 10^{-16}$ \\
$\left(\mathrm{SO}_{4}{ }^{-}-3.27\right)^{2}\left(\beta_{3}\right)$ & -0.008 & 0.001 & -5.74 & $4.5 \times 10^{-8}$ \\
$\mathrm{Mg}^{2+}\left(\beta_{4}\right)$ & -3.83 & 1.45 & -2.65 & 0.0089
\end{tabular}

Residual standard error: 0.1672 on 161 degrees of freedom. Multiple R-squared: 0.94. Adjusted R-squared: 0.94 F-statistic: 636.3 on 4 and $161 \mathrm{DF}, p$-value: $<2.2 \times 10^{-16}$

Table 2. The summary of final MLR model coefficients at the YRK site from 2012 to 2016.

\begin{tabular}{ccccc}
\hline Predictors & Coefficients & SE & t value & Pr $>|\mathbf{t}|$ \\
\hline Intercept $\left(\beta_{0}\right)$ & 0.028 & 0.027 & 1.03 & 0.31 \\
$\mathrm{SO}_{4}{ }^{2-}\left(\beta_{1}\right)$ & 0.38 & 0.013 & 29.58 & $<2 \times 10^{-16}$ \\
$\mathrm{NO}_{3}-\left(\beta_{2}\right)$ & 0.067 & 0.032 & 2.12 & 0.036 \\
$\left(\mathrm{NO}_{3}^{-}-0.41\right)^{2}\left(\beta_{3}\right)$ & 0.155 & 0.028 & 5.62 & $1.23 \times 10^{-7}$ \\
$\mathrm{Na}^{+}\left(\beta_{4}\right)$ & -0.54 & 0.132 & -4.1 & $7.48 \times 10^{-5}$ \\
$\mathrm{~T}\left(\beta_{5}\right)$ & -0.0025 & 0.00149 & -1.67 & 0.097 \\
$\left(\mathrm{Na}^{+}-0.04\right)^{2}\left(\beta_{6}\right)$ & 0.71 & 0.29 & 2.43 & 0.0166 \\
$\mathrm{HNO}_{3}\left(\beta_{7}\right)$ & -0.045 & 0.027 & -1.66 & 0.0995 \\
$\mathrm{~K}^{+}\left(\beta_{8}\right)$ & 0.87 & 0.38 & 2.31 & 0.0226 \\
$\mathrm{SO}_{4}{ }^{2-}: \mathrm{T}\left(\beta_{9}\right)$ & -0.0029 & 0.000684 & -4.24 & $4.39 \times 10^{-5}$ \\
$\mathrm{~T}: \mathrm{HNO}_{3}\left(\beta_{10}\right)$ & 0.0045 & 0.0014 & 3.25 & 0.00149 \\
\hline
\end{tabular}

Residual standard error: 0.05419 on 122 degrees of freedom. Multiple R-squared: 0.97. Adjusted R-squared: 0.97 . F-statistic: 443.7 on 10 and $122 \mathrm{DF}, p$-value: $<2.2 \times 10^{-16}$.

In the linear regression analysis, the interaction terms may cause serious multicollinearity problem, which will provide redundant information [58]; thus, the model diagnostics may exclude the interaction terms when the variance inflation factor (VIF) for interaction term is greater than 10 . The selection of predictor variables varied at different sites in different periods.

Both $\mathrm{SO}_{4}{ }^{2-}$ and $\mathrm{NO}_{3}{ }^{-}$were included in the regression models at the six sites in two periods. The iPM $\mathrm{PM}_{2.5}$ mainly consisted of $\mathrm{NH}_{4}{ }^{+}$salts, most of the $\mathrm{NH}_{4}{ }^{+}$cations were associated with $\mathrm{SO}_{4}{ }^{2-}$ and $\mathrm{NO}_{3}{ }^{-}$anions. The coefficients for both $\mathrm{SO}_{4}{ }^{2-}$ and $\mathrm{NO}_{3}{ }^{-}$were positive, which indicated the positive correlation between cation- $\mathrm{NH}_{4}{ }^{+}$and anions- $\mathrm{SO}_{4}{ }^{2-}$ and $\mathrm{NO}_{3}{ }^{-}$. The positive regression coefficients $(0.29-0.38)$ for $\mathrm{SO}_{4}{ }^{2-}$ were greater than the coefficients for all the other predictor variables. The dominance of particle-phase $\mathrm{SO}_{4}{ }^{2-}$ salts led to the significant relationship between $\mathrm{NH}_{4}{ }^{+}$and $\mathrm{SO}_{4}{ }^{2-}$; the changes in $\mathrm{SO}_{4}{ }^{2-}$ can cause corresponding changes in $\mathrm{NH}_{4}{ }^{+}$. Some centered quadratic terms were included in the model as well, the quadratic terms indicated that the direction of the relationship 
between $\mathrm{NH}_{4}{ }^{+}$and $\mathrm{SO}_{4}{ }^{2-}, \mathrm{NO}_{3}{ }^{-}$may change as $\mathrm{SO}_{4}{ }^{2-}$ and $\mathrm{NO}_{3}{ }^{-}$concentrations changed. The complex relationship between $\mathrm{NH}_{4}{ }^{+}$and $\mathrm{SO}_{4}{ }^{2-}, \mathrm{NO}_{3}{ }^{-}$may be caused by reactions between $\mathrm{NH}_{3}$ and $\mathrm{H}_{2} \mathrm{SO}_{4}, \mathrm{HNO}_{3}$, the dynamic changes in particle-phase $\mathrm{SO}_{4}{ }^{2-} ; \mathrm{NO}_{3}{ }^{-}$ may also change the dynamic reactions of $\mathrm{NH}_{3}$ and various acidic gases (e.g., the free $\mathrm{NH}_{3}$ from the reduction in $\mathrm{SO}_{4}{ }^{2-}$ may react with $\mathrm{HNO}_{3}$ to form $\mathrm{NH}_{4} \mathrm{NO}_{3}$ ).

As for the gas-phase $\mathrm{NH}_{3}$, the BIC step-wise model selection method did not include $\mathrm{NH}_{3}$ in the MLR model at the JST site in 2010-2011, at the YRK site in 2008-2011 and 2012-2016, and at the BHM site in 2012-2016. The exclusion of $\mathrm{NH}_{3}$ indicated that $\mathrm{NH}_{3}$ may not limit the formation of $\mathrm{NH}_{4}{ }^{+}$salts at these three sites. Specifically, $\mathrm{NH}_{3}$ was excluded from the regression model from 2008 to 2016 at the YRK site. The $\mathrm{NH}_{3}$ emissions from AFOs contributed to the abundant $\mathrm{NH}_{3}$ gas at the YRK site; thus, the $\mathrm{NH}_{3}$-rich conditions dominated. While for the CTR site (Table S16) in 2012-2016, OAK site (Table S17) in 2010, and OLF site (Table S18) in 2013-2016, the $\mathrm{NH}_{3}$ was included in the regression model and the coefficients were positive. Especially, at the OAK site, coefficient of $\mathrm{NH}_{3}$ was 0.16 , which was higher than the other sites. The positive coefficients suggested that the higher $\mathrm{NH}_{3}$ led to increased formation of $\mathrm{NH}_{4}{ }^{+}$salts at these sites.

As for the gas-phase $\mathrm{HNO}_{3}$, it was included in the regression model at the YRK site in 2012-2016, and at the BHM site in 2011, and the regression coefficients for $\mathrm{HNO}_{3}$ in these two models were negative. The semi-volatile characteristic of $\mathrm{NH}_{4} \mathrm{NO}_{3}$ may explain the negative coefficient. Under ambient conditions, such as high $\mathrm{T}$ and low $\mathrm{RH}$, the $\mathrm{NH}_{4} \mathrm{NO}_{3}$ may decompose into gas-phase $\mathrm{NH}_{3}$ and $\mathrm{HNO}_{3}$, the increase in gas-phase $\mathrm{HNO}_{3}$ leads to a decrease in $\mathrm{NH}_{4}{ }^{+}$. The interaction term- $\mathrm{T}: \mathrm{HNO}_{3}$ at the YRK site, may indicate the dependence of the formation of $\mathrm{NH}_{4} \mathrm{NO}_{3}$ on ambient conditions.

As for ambient meteorological conditions- $\mathrm{T}$ and $\mathrm{RH}$, only $\mathrm{T}$ was included in the regression models at the JST site in 2012-2016 (Table S13), at the YRK site in 2012-2016 (Table 2), at the BHM site in 2011 (Table S14) and 2012-2016 (Table S15), and at the OAK site in 2010 (Table S17). The RH was excluded from all the regression models. The coefficients for $\mathrm{T}$ were all negative, which indicated that the increase in $\mathrm{T}$ led to the decrease in $\mathrm{NH}_{4}{ }^{+}$, but the coefficients for $\mathrm{T}$ were smaller compared to the coefficients for the other predictor variables. The smaller coefficient for $\mathrm{T}$ may indicate the relatively weak impact of $\mathrm{T}$ on the $\mathrm{NH}_{4}{ }^{+}$.

As for the NVCs and $\mathrm{Cl}^{-}$, although the concentrations were lower compared with the other gas- and particle-phase species, one of $\mathrm{Mg}^{2+}, \mathrm{Na}^{+}$, or $\mathrm{Cl}^{-}$was included in the regression models, this indicated that the $\mathrm{NVCs}$ and $\mathrm{Cl}^{-}$were important factors affecting the $\mathrm{NH}_{4}{ }^{+}$concentration. The coefficients for $\mathrm{Mg}^{2+}$ may exhibit some large values (e.g., -6.69 and -3.83 ), which indicated that there is a strong negative correlation between $\mathrm{Mg}^{2+}$ and $\mathrm{NH}_{4}{ }^{+}$. However, ISORROPIA II model simulation implicated that the low concentration of $\mathrm{Mg}^{2+}$ may not lead to a significant change in $\mathrm{NH}_{4}{ }^{+}$concentration, which is against MLR model results.

\section{Conclusions}

In this research, the effects of changes in precursor gases on the formation of $\mathrm{iPM}_{2.5}$ as well as the partitioning of $\mathrm{NH}_{3}-\mathrm{NH}_{4}{ }^{+}$were investigated using ISORROPIA II modeling approach with inputs of field measurements of gas-phase and particle-phase pollutants and meteorological data in the SEARCH network. The results indicated that the reduction in total $\mathrm{H}_{2} \mathrm{SO}_{4}$ was more effective to decrease the formation of $\mathrm{PPM}_{2.5}$, especially under $\mathrm{NH}_{3}$-rich conditions. In addition, the reduction in total $\mathrm{H}_{2} \mathrm{SO}_{4}$ may change the partitioning of $\mathrm{NH}_{3}-\mathrm{NH}_{4}{ }^{+}$towards gas-phase. Moreover, the reduction in total $\mathrm{H}_{2} \mathrm{SO}_{4}$ may lead to an increase in $\mathrm{NO}_{3}{ }^{-}$when $\mathrm{NH}_{3}$ was not in excess to neutralize the acidic gases. Thus, the future reduction in $\mathrm{PPM}_{2.5}$ may necessitate the coordinated reduction in both $\mathrm{H}_{2} \mathrm{SO}_{4}$ and $\mathrm{HNO}_{3}$ in the southeastern U.S. It was also discovered that the response of $\mathrm{iPM}_{2.5}$ to the change in total $\mathrm{H}_{2} \mathrm{SO}_{4}$ was more sensitive in summer than winter. The dominance of $\mathrm{SO}_{4}{ }^{2-}$ salts in $\mathrm{iPM}_{2.5}$ and high $\mathrm{T}$ in summer did not facilitate the formation of $\mathrm{NH}_{4} \mathrm{NO}_{3}$, the decrease in $\mathrm{SO}_{4}{ }^{2-}$ salts caused by the reduction in total $\mathrm{H}_{2} \mathrm{SO}_{4}$ will not be offset by the 
increase in the $\mathrm{NO}_{3}{ }^{-}$salts. The significant $\mathrm{NH}_{3}$ emissions from AFOs in the agricultural rural area had great impact on the partitioning of $\mathrm{NH}_{3}-\mathrm{NH}_{4}{ }^{+}$, and the $\mathrm{NH}_{3}$ emissions from the AFOs led to the elevated $\mathrm{NH}_{3}$ concentration, which was in excess to neutralize acidic gases. The formation of $\mathrm{NH}_{4} \mathrm{NO}_{3}$ was not affected by the reduction in total $\mathrm{H}_{2} \mathrm{SO}_{4}$ in an agricultural rural area. The BIC stepwise model selection determined the MLR model to predict $\mathrm{NH}_{4}{ }^{+}$at six sites, there was a strong positive correlation between cation- $\mathrm{NH}_{4}{ }^{+}$ and anions $-\mathrm{SO}_{4}{ }^{2-}$ and $\mathrm{NO}_{3}{ }^{-}$. The $\mathrm{NH}_{3}$ was excluded from the regression model at the YRK site due to the abundant $\mathrm{NH}_{3}$ emitted from AFOs, and the $\mathrm{NVCs}$ and $\mathrm{Cl}^{-}$were the significant impact factors affecting $\mathrm{NH}_{4}{ }^{+}$concentrations.

Supplementary Materials: The following are available online at https:/ / www.mdpi.com/article/10 .3390 /atmos12121681/s1, Table S1: Field measurements at the eight sites, Table S2: The statistics of different precursor gases of $\mathrm{PPM}_{2.5}$ by season at the YRK site in 2008-2011, Table S3: The statistics of different precursor gases of $\mathrm{PPM}_{2.5}$ by season at the YRK site in 2012-2016, Table S4: The statistics of different precursor gases of $\mathrm{PPM}_{2.5}$ by season at the JST site in 2010-2011, Table S5: The statistics of different precursor gases of $\mathrm{PPM}_{2.5}$ by season at the JST site in 2012-2016, Table S6: The statistics of different precursor gases of $\mathrm{iPM}_{2.5}$ by season at the CTR site in 2012-2016, Table S7: The statistics of different precursor gases of $\mathrm{iPM}_{2.5}$ by season at the BHM site in 2011, Table S8: The statistics of different precursor gases of $\mathrm{iPM}_{2.5}$ by season at the BHM site in 2012-2016, Table S9: The statistics of different precursor gases of $\mathrm{iPM}_{2.5}$ by season at the OAK site in 2010, Table S10: The statistics of different precursor gases of $\mathrm{iPM}_{2.5}$ by season at the OLF site in 2013-2016, Table S11: The summary of aerosol pH at five sites in 2012 to 2016, Table S12: The summary of final MLR model coefficients at the JST site from 2010 to 2011, Table S13: The summary of final MLR model coefficients at the JST site from 2012 to 2016, Table S14: The summary of final MLR model coefficients at the BHM site in 2011, Table S15: The summary of final MLR model coefficients at the BHM site from 2012 to 2016, Table S16: The summary of final MLR model coefficients at the CTR site from 2012 to 2016, Table S17: The summary of final MLR model coefficients at the OAK site in 2010, Table S18: The summary of final MLR model coefficients at the OLF site from 2013 to 2016, Figure S1: Responses of $\mathrm{iPM}_{2.5}, \mathrm{NH}_{4}{ }^{+}$, and $\mathrm{NH}_{3} / \mathrm{NH}_{\mathrm{x}}$ to the changes of TNH3 and THNO3 at the JST site in summer and winter of 2012-2016, Figure S2: Responses of $\mathrm{iPM}_{2.5}, \mathrm{NH}_{4}{ }^{+}$, and $\mathrm{NH}_{3} / \mathrm{NH}_{\mathrm{x}}$ to the changes of $\mathrm{TNH}_{3}$ and $\mathrm{THNO}_{3}$ at the CTR site in summer and winter of 2012-2016, Figure S3: Responses of $\mathrm{iPM}_{2.5}, \mathrm{NH}_{4}{ }^{+}$, and $\mathrm{NH}_{3} / \mathrm{NH}_{\mathrm{x}}$ to the changes of $\mathrm{TNH}_{3}$ and $\mathrm{THNO}_{3}$ at the $\mathrm{BHM}$ site in summer and winter of 2012-2016, Figure S4: Responses of $\mathrm{iPM}_{2.5}, \mathrm{NH}_{4}{ }^{+}$, and $\mathrm{NH}_{3} / \mathrm{NH}_{\mathrm{x}}$ to the changes of $\mathrm{TNH}_{3}$ and $\mathrm{THNO}_{3}$ at the OLF site in summer and winter of 2013-2016, Figure S5: Responses of $\mathrm{iPM}_{2.5}, \mathrm{NH}_{4}{ }^{+}$, and $\mathrm{NH}_{3} / \mathrm{NH}_{\mathrm{x}}$ to the changes of $\mathrm{TNH}_{3}$ and $\mathrm{TH}_{2} \mathrm{SO}_{4}$ at the JST site in summer and winter of 2012-2016, Figure S6: Responses of $\mathrm{iPM}_{2.5}, \mathrm{NH}_{4}{ }^{+}$, and $\mathrm{NH}_{3} / \mathrm{NH}_{\mathrm{x}}$ to the changes of $\mathrm{TNH}_{3}$ and $\mathrm{TH}_{2} \mathrm{SO}_{4}$ at the CTR site in summer and winter of 2012-2016, Figure S7: Responses of iPM 2.5 , $\mathrm{NH}_{4}{ }^{+}$, and $\mathrm{NH}_{3} / \mathrm{NH}_{\mathrm{x}}$ to the changes of $\mathrm{TNH}_{3}$ and $\mathrm{TH}_{2} \mathrm{SO}_{4}$ at the $\mathrm{BHM}$ site in summer and winter of 2012-2016, Figure S8: Responses of $\mathrm{iPM}_{2.5}, \mathrm{NH}_{4}{ }^{+}$, and $\mathrm{NH}_{3} / \mathrm{NH}_{\mathrm{x}}$ to the changes of $\mathrm{TNH}_{3}$ and $\mathrm{TH}_{2} \mathrm{SO}_{4}$ at the OLF site in summer and winter of 2013-2016, Figure S9: Responses of $\mathrm{PPM}_{2.5}, \mathrm{SO}_{4}{ }^{2-}$, $\mathrm{NH}_{4}{ }^{+}, \mathrm{NO}_{3}{ }^{-}, \mathrm{NH}_{3} / \mathrm{NH}_{\mathrm{x}}$, and GR to the reductions in $\mathrm{TNH}_{3}$ at the BHM site in 2012-2016, Figure S10: Responses of $\mathrm{iPM}_{2.5}, \mathrm{SO}_{4}{ }^{2-}, \mathrm{NH}_{4}{ }^{+}, \mathrm{NO}_{3}{ }^{-}, \mathrm{NH}_{3} / \mathrm{NH}_{\mathrm{x}}$, and GR to the reductions in $\mathrm{THNO}_{3}$ at the BHM site in 2012-2016, Figure S11: Responses of $\mathrm{iPM}_{2.5}, \mathrm{SO}_{4}{ }^{2-}, \mathrm{NH}_{4}{ }^{+}, \mathrm{NO}_{3}{ }^{-}, \mathrm{NH}_{3} / \mathrm{NH}_{\mathrm{x}}$, and GR to the reductions in $\mathrm{TH}_{2} \mathrm{SO}_{4}$ at the BHM site in 2012-2016, Figure S12: Responses of $\mathrm{PPM}_{2.5}, \mathrm{SO}_{4}{ }^{2-}$, $\mathrm{NH}_{4}{ }^{+}, \mathrm{NO}_{3}{ }^{-}, \mathrm{NH}_{3} / \mathrm{NH}_{\mathrm{x}}$, and GR to the reductions in $\mathrm{TNH}_{3}$ at the CTR site in 2012-2016, Figure S13: Responses of $\mathrm{iPM}_{2.5}, \mathrm{SO}_{4}{ }^{2-}, \mathrm{NH}_{4}{ }^{+}, \mathrm{NO}_{3}{ }^{-}, \mathrm{NH}_{3} / \mathrm{NH}_{\mathrm{x}}$, and $\mathrm{GR}$ to the reductions in $\mathrm{THNO}_{3}$ at the CTR site in 2012-2016, Figure S14: Responses of $\mathrm{iPM}_{2.5}, \mathrm{SO}_{4}{ }^{2-}, \mathrm{NH}_{4}{ }^{+}, \mathrm{NO}_{3}{ }^{-}, \mathrm{NH}_{3} / \mathrm{NH}_{\mathrm{x}}$, and GR to the reductions in $\mathrm{TH}_{2} \mathrm{SO}_{4}$ at the CTR site in 2012-2016, Figure S15: Responses of $\mathrm{iPM}_{2.5}, \mathrm{SO}_{4}{ }^{2-}$, $\mathrm{NH}_{4}{ }^{+}, \mathrm{NO}_{3}{ }^{-}, \mathrm{NH}_{3} / \mathrm{NH}_{\mathrm{x}}$, and GR to the reductions in $\mathrm{TNH}_{3}$ at the JST site in 2012-2016, Figure S16: Responses of $\mathrm{iPM}_{2.5}, \mathrm{SO}_{4}{ }^{2-}, \mathrm{NH}_{4}{ }^{+}, \mathrm{NO}_{3}{ }^{-}, \mathrm{NH}_{3} / \mathrm{NH}_{\mathrm{x}}$, and $\mathrm{GR}$ to the reductions in $\mathrm{THNO}_{3}$ at the JST site in 2012-2016, Figure S17: Responses of $\mathrm{iPM}_{2.5}, \mathrm{SO}_{4}{ }^{2-}, \mathrm{NH}_{4}{ }^{+}, \mathrm{NO}_{3}{ }^{-}, \mathrm{NH}_{3} / \mathrm{NH}_{\mathrm{x}}$, and GR to the reductions in $\mathrm{TH}_{2} \mathrm{SO}_{4}$ at the JST site in 2012-2016, Figure S18: Responses of $\mathrm{iPM}_{2.5}, \mathrm{SO}_{4}{ }^{2-}$, $\mathrm{NH}_{4}{ }^{+}, \mathrm{NO}_{3}{ }^{-}, \mathrm{NH}_{3} / \mathrm{NH}_{\mathrm{x}}$, and GR to the reductions in $\mathrm{TNH}_{3}$ at the OLF site in 2013-2016, Figure S19: Responses of $\mathrm{iPM}_{2.5}, \mathrm{SO}_{4}{ }^{2-}, \mathrm{NH}_{4}{ }^{+}, \mathrm{NO}_{3}{ }^{-}, \mathrm{NH}_{3} / \mathrm{NH}_{\mathrm{x}}$, and GR to the reductions in $\mathrm{THNO}_{3}$ at the OLF site in 2013-2016, Figure S20: Responses of $\mathrm{iPM}_{2.5}, \mathrm{SO}_{4}{ }^{2-}, \mathrm{NH}_{4}{ }^{+}, \mathrm{NO}_{3}{ }^{-}, \mathrm{NH}_{3} / \mathrm{NH}_{\mathrm{x}}$, and GR to the reductions in $\mathrm{TH}_{2} \mathrm{SO}_{4}$ at the OLF site in 2013-2016. 
Author Contributions: Conceptualization, B.C. and L.W.-L.; methodology, B.C. and L.W.-L.; project administration, L.W.-L.; data analysis, B.C. and L.W.-L., data interpretation, B.C., L.W.-L., N.M., J.C. and P.B.; writing-original draft preparation, B.C.; writing-review and editing, B.C., L.W.-L. and N.M.; funding acquisition, L.W.-L. All authors have read and agreed to the published version of the manuscript.

Funding: This work was supported in part by NSF Award No. CBET-1804720.

Institutional Review Board Statement: Not applicable.

Informed Consent Statement: Not applicable.

Data Availability Statement: Publicly available datasets were analyzed in this study. This data can be found here: (https:/ / www.dropbox.com/sh/o9hxoa4wlo97zpe/AACbm6LetQowrpUgX4 vUxnoDa?dl=0 (accessed on 3 October 2021)).

Acknowledgments: Great thanks to Eric Edgerton from ARA, Inc. for providing the SEARCH network data.

Conflicts of Interest: The authors declare no conflict of interest. The funders had no role in the design of the study; in the collection, analyses, or interpretation of data; in the writing of the manuscript, or in the decision to publish the results.

\section{References}

1. Geng, G.; Zhang, Q.; Tong, D.; Li, M.; Zheng, Y.; Wang, S.; He, K. Chemical composition of ambient $\mathrm{PM}_{2.5}$ over China and relationship to precursor emissions during 2005-2012. Atmos. Chem. Phys. 2017, 17, 9187-9203. [CrossRef]

2. Heederik, D.; Sigsgaard, T.; Thorne, P.S.; Kline, J.N.; Avery, R.; Bonlokke, J.H.; Chrischilles, E.A.; Dosman, J.A.; Duchaine, C.; Kirkhorn, S.R.; et al. Health effects of airborne exposures from concentrated animal feeding operations. Environ. Health Perspect. 2007, 115, 298-302. [CrossRef]

3. Pope, C., III; Ezzati, M.; Dockery, D.W. Fine-particulate air pollution and life expectancy in the United States. N. Engl. J. Med. 2009, 360, 376-386. [CrossRef] [PubMed]

4. Pui, D.Y.H.; Chen, S.; Zuo, Z. PM 2.5 in China: Measurements, sources, visibility and health effects, and mitigation. Particuology 2014, 13, 1-26. [CrossRef]

5. USEPA. Glossary. 2015. Available online: http://www.epa.gov/airquality/airdata/ad_glossary.html (accessed on 19 October 2018).

6. Andrews, E.; Saxena, P.; Musarra, S.; Hildemann, L.M.; Koutrakis, P.; McMurry, P.H.; Olmez, I.; White, W.H. Concentration and composition of atmospheric aerosols from the 1995 SEAVS experiment and a review of the closure between chemical and gravimetric measurements. J. Air Waste Manag. Assoc. 2000, 50, 648-664. [CrossRef]

7. Bell, M.L.; Dominici, F.; Ebisu, K.; Zeger, S.L.; Samet, J.M. Spatial and temporal variation in PM $_{2.5}$ chemical composition in the United States for health effects studies. Environ. Health Perspect. 2007, 115, 989-995. [CrossRef] [PubMed]

8. Chow, J.C.; Lowenthal, D.H.; Chen, L.W.A.; Wang, X.; Watson, J.G. Mass reconstruction methods for PM 2.5 : A review. Air Qual. Atmos. Health 2015, 8, 243-263. [CrossRef] [PubMed]

9. Frank, N.H. Retained nitrate, hydrated sulfates, and carbonaceous mass in federal reference method fine particulate matter for six eastern U.S. cities. J. Air Waste Manag. Assoc. 2006, 56, 500-511. [CrossRef] [PubMed]

10. Solomon, P.A.; Crumpler, D.; Flanagan, J.B.; Jayanty, R.K.M.; Rickman, E.E.; McDade, C.E. U.S. National PM 2.5 Chemical Speciation Monitoring Networks-CSN and IMPROVE: Description of networks. J. Air Waste Manag. Assoc. 2014, 64, 1410-1438. [CrossRef] [PubMed]

11. Hinds, W.C. Aerosol Technology: Properties, Behavior and Measurement of Airborne Particles, 2nd ed.; John Wiley \& Sons: New York, NY, USA, 1998.

12. Tolocka, M.P.; Solomon, P.A.; Mitchell, W.; Norris, G.A.; Gemmill, D.B.; Wiener, R.W.; Vanderpool, R.W.; Homolya, J.B.; Rice, J. East versus west in the US: Chemical characteristics of $\mathrm{PM}_{2.5}$ during the winter of 1999. Aerosol Sci. Technol. 2001, 34, 88-96. [CrossRef]

13. Cheng, B.; Shiv Kumar, A.P.; Wang-Li, L. Inverse AERMOD and SCIPUFF dispersion modeling for farm level PM 10 emission rate assessment. Trans. ASABE 2021, 64, 801-817. [CrossRef]

14. Li, Y.; Thompson, T.M.; Damme, M.V.; Chen, X.; Benedict, K.B.; Shao, Y.; Day, D.; Boris, A.; Sullivan, A.P.; Ham, J.; et al. Temporal and spatial variability of ammonia in urban and agricultural regions of northern Colorado, United States. Atmos. Chem. Phys. 2017, 17, 6197-6213. [CrossRef]

15. Guo, H.; Liu, J.; Froyd, K.D.; Roberts, J.M.; Veres, P.R.; Hayes, P.L.; Jimenez, J.L.; Nenes, A.; Weber, R.J. Fine particle pH and gas-particle phase partitioning of inorganic species in Pasadena, California, during the 2010 CalNex campaign. Atmos. Chem. Phys. 2017, 17, 5703-5719. [CrossRef]

16. Tanner, R.L.; Marlow, W.H.; Newman, L. Chemical composition correlations of size-fractionated sulfate in New York City. Am. Chem. Soc. 1979, 13, 75-78. [CrossRef] 
17. Li, Q.-F.; Wang-Li, L.; Liu, Z.; Beasley, D.B. Chemical characterization of particulate matter emitted from animal feeding operations; ASABE paper No. 095948. In Proceedings of the 2009 ASABE Annual International Meeting, Reno, NV, USA, $21-24$ June 2009.

18. Li, Q.-F. Particulate Matter from an Egg Production Facility: Emission, Chemistry and Local Dispersion. Ph.D. Thesis, North Carolina State University, Raleigh, NC, USA, 2012.

19. Li, Q.-F.; Wang-Li, L.; Shah, S.B.; Jayanty, R.K.M.; Bloomfield, P. Ammonia concentrations and modeling of inorganic particulate matter in the vicinity of an egg production facility in Southeastern USA. Environ. Sci. Pollut. Res. 2014, 21, 4675-4685. [CrossRef] [PubMed]

20. Walker, J.T.; Whitall, D.R.; Robarge, W.; Paerl, H.W. Ambient ammonia and ammonium aerosol across a region of variable ammonia emission density. Atmos. Environ. 2004, 38, 1235-1246. [CrossRef]

21. Cheng, B.; Wang-Li, L. Spatial and temporal variations of $\mathrm{PM}_{2.5}$ in North Carolina. Aerosol Air Qual. Res. 2019, 19, 698-710. [CrossRef]

22. Hildemann, L.M.; Russell, A.G.; Cass, G.R. Ammonia and nitric acid concentration in equilibrium with atmospheric aerosols: Experiment vs. theory. Atmos. Environ. 1984, 18, 1737-1750. [CrossRef]

23. Dawson, J.P.; Adam, P.J.; Pandis, S.N. Sensitivity of $\mathrm{PM}_{2.5}$ to climate in the Eastern U.S.: A modeling case study. Atmos. Chem. Phys. 2007, 7, 4295-4309. [CrossRef]

24. Seinfeld, J.H.; Pandis, S.N. Atmospheric Chemistry and Physics: From Air Pollution to Climate Change, 2nd ed.; John Wiley \& Sons: New York, NY, USA, 2006.

25. Ansari, A.S.; Pandis, S.N. Response of inorganic PM to precursor concentrations. Environ. Sci. Technol. 1998, 32, 2706-2714. [CrossRef]

26. Guo, H.; Otjes, R.; Schlag, P.; Kiendler-Scharr, A.; Nenes, A.; Weber, R.J. Effectiveness of ammonia reduction on control of fine particle nitrate. Atmos. Chem. Phys. 2018, 18, 12241-12256. [CrossRef]

27. Cheng, B.; Wang-Li, L. Responses of secondary inorganic $\mathrm{PM}_{2.5}$ to precursor gases in an ammia abundant area in North Carolina. Aerosol Air Qual. Res. 2019, 19, 1126-1138. [CrossRef]

28. Nah, T.; Guo, H.; Sullivan, A.P.; Chen, Y.; Tanner, D.J.; Nenes, A.; Russell, A.; Ng, N.L.; Huey, L.G.; Weber, R.J. Characterization of aerosol composition, aerosol acidity, and organic acid partitioning at an agriculturally intensive rural southeastern US site. Atmos. Chem. Phys. 2018, 18, 11471-11491. [CrossRef]

29. Nenes, A.; Pilinis, C.; Pandis, S.N. ISORROPIA: A new thermodynamic equilibrium model for multiphase multicomponent inorganic aerosols. Aqua. Geochem. 1998, 4, 123-152. [CrossRef]

30. Nenes, A.; Pilinis, C.; Pandis, S.N. Continued development and testing of a new thermodynamic aerosol module for urban and regional air quality models. Atmos. Environ. 1999, 33, 1553-1560. [CrossRef]

31. Fountoukis, C.; Nenes, A. ISORROPIA II: A computationally efficient thermodynamic equilibrium model for $\mathrm{K}^{+}-\mathrm{Ca}^{2+}-\mathrm{Mg}^{2+}{ }_{-}$ $\mathrm{NH}_{4}{ }^{+}-\mathrm{Na}^{+}-\mathrm{SO}_{4}{ }^{2-}-\mathrm{NO}_{3}{ }^{-}-\mathrm{Cl}^{-}-\mathrm{H}_{2} \mathrm{O}$ aerosols. Atmos. Chem. Phys. Discuss. 2007, 7, 1893-1939.

32. Fountoukis, C.; Nenes, A.; Sullivan, A.; Weber, R.; Van Reken, T.; Fischer, M.; Matias, E.; Moya, M.; Farmer, D.; Cohen, R.C. Thermodynamic characterization of Mexico City aerosol during MILAGRO 2006. Atmos. Chem. Phys. 2009, 9, $2141-2156$. [CrossRef]

33. Walker, J.T.; Robarge, W.P.; Shendrikar, A.; Kimball, H. Inorganic $\mathrm{PM}_{2.5}$ at a U.S. agricultural site. Environ. Pollut. 2006, 139, 258-271. [CrossRef]

34. Li, Q.-F.; Wang-Li, L.; Liu, Z.; Jayanty, R.K.M.; Shah, S.B.; Bloomfield, P. Major ionic composition of fine particulate matter in an animal feeding operation facility and its vicinity. J. Air Waste Manag. Assoc. 2014, 64, 1279-1287. [CrossRef]

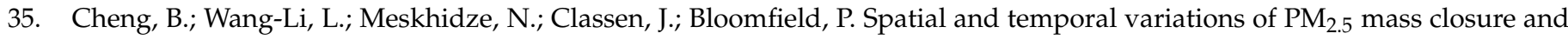
inorganic $\mathrm{PM}_{2.5}$ in the Southeastern U.S. Environ. Sci. Pollut. Res. 2019, 26, 33181-33319. [CrossRef]

36. Cheng, B.; Wang-Li, L.; Classen, J.; Meskhidze, N.; Bloomfield, P. Spatial and temporal variations of atmospheric chemical condition in the Southeastern U.S. Environ. Atmos. Res. 2021, 248, 105190. [CrossRef]

37. Wang-Li, L. Insights to the formation of secondary inorganic $\mathrm{PM}_{2.5}$ : Current knowledge and future needs. IJABE 2015, 8, 1-13.

38. Blanchard, C.L.; Hidy, G.M. Effects of changes in sulfate, ammonia, and nitric acid on particulate nitrate concentrations in the Southeastern United States. J. Air Waste Manag. Assoc. 2003, 53, 283-290. [CrossRef]

39. Blanchard, C.L.; Hidy, G.M. Effects of $\mathrm{SO}_{2}$ and $\mathrm{NO}_{x}$ emission reductions on $\mathrm{PM}_{2.5}$ mass concentrations in the Southeastern United States. J. Air Waste Manag. Assoc. 2005, 55, 265-272. [CrossRef] [PubMed]

40. Blanchard, C.L.; Tanenbaum, S.; Hidy, G.M. Effects of sulfur dioxide and oxides of nitrogen emission reductions on fine particulate matter mass concentrations: Regional comparisons. J. Air Waste Manag. Assoc. 2007, 57, 1337-1350. [CrossRef]

41. Edgerton, E.S.; Saylor, R.D.; Hartsell, B.E.; Jansen, J.J.; Hansen, D.A. Ammonia and ammonium measurements from the southeastern United States. Atmos. Environ. 2007, 41, 3339-3351. [CrossRef]

42. USEPA. NAAQS Table. 2018. Available online: https://www.epa.gov/criteria-air-pollutants/naaqs-table (accessed on 18 March 2018).

43. USEPA. Clean Air Interstate Rule. 2018. Available online: https://www.tceq.texas.gov/airquality/sip/caircamr.html (accessed on 18 March 2018).

44. USEPA. Cross-State Air Pollution Rule. 2018. Available online: https://www.epa.gov/csapr (accessed on 18 March 2018).

45. Cheng, B. Dynamics of Rural and Urban Atmospheric Chemical Conditions and Inorganic Aerosols. Ph.D. Thesis, North Carolina State University, Raleigh, NC, USA, 2018. 
46. Hansen, D.A.; Edgerton, E.S.; Hartsell, B.E.; Jansen, J.J.; Kandasamy, N.; Hidy, G.M.; Blanchard, C.L. The Southeastern Aerosol Research and Characterization Study: Part 1-Overview. J. Air Waste Manag. Assoc. 2003, 53, 1460-1471. [CrossRef] [PubMed]

47. Cohen, M.A.; Ryan, P.B. Observations less than the analytical limit of Detection: A new approach. JAPCA 1989, 39, 328-329. [CrossRef]

48. USEPA. Guidance for Data Quality Assessment. 2000. Available online: https://www.epa.gov/sites/production/files/2015-06/ documents / g9-final.pdf (accessed on 19 October 2018).

49. Ellis, R.A.; Murphy, J.G.; Markovic, M.Z.; VandenBoer, T.C.; Makar, P.A.; Brook, J.; Mihele, C. The influence of gas-particle partitioning and surface-atmosphere exchange on ammonia during BAQS-Met. Atmos. Chem. Phys. 2011, 11, 133-145. [CrossRef]

50. Saylor, R.D.; Myles, L.; Sibble, D.; Caldwell, J.; Xing, X. Recent trends in gas-phase ammonia and PM 2.5 ammonium in the Southeast United States. J. Air Waste Manag. Assoc. 2015, 65, 347-357. [CrossRef]

51. Dong, X.; Li, J.; Fu, J.; Gao, Y.; Huang, K.; Zhuang, G. Inorganic aerosols responses to emission changes in Yangtze River Delta, China. Sci. Total Environ. 2014, 481, 522-532. [CrossRef] [PubMed]

52. Guo, H.; Nenes, A.; Weber, R.J. The underappreciated role of nonvolatile cations in aerosol ammonium-sulfate molar ratios. Atmos. Chem. Phys. 2018, 18, 17307-17323. [CrossRef]

53. Cheng, B.; Wang-Li, L.; Classen, J.; Bloomfield, P. Performance of a thermodynamic model for predicting inorganic aerosols in the Southeastern U.S. Aerosol Air Qual. Res. 2021. under review.

54. Lei, L.; Xie, C.; Wang, D.; He, Y.; Wang, Q.; Zhou, W.; Hu, W.; Fu, P.; Chen, Y.; Pan, X.; et al. Fine particle characterization in a coastal city in China: Composition, sources, and impacts of industrial emissions. Atmos. Chem. Phys. 2020, 20, 2877-2890. [CrossRef]

55. Lim, Y.B.; Seo, J.; Kim, J.Y.; Kim, Y.P.; Jin, H.C. Local formation of sulfates contributes to the urban haze with regional transport origin. Environ. Res. Lett. 2020, 15, 084034. [CrossRef]

56. Alexa, L.; Mikuska, P. Simultaneous determination of gaseous ammonia and particulate ammonium in ambient air using a cylindrical wet effluent diffusion denuder and a continuous aerosol sampler. Anal. Chem. 2020, 92, 15827-15836. [CrossRef]

57. Olszyna, K.J.; Bairai, S.T.; Tanner, R.L. Effect of ambient $\mathrm{NH}_{3}$ levels on $\mathrm{PM}_{2.5}$ compositions in the Great Smoky Mountains National Park. Atmos. Environ. 2005, 39, 4593-4606. [CrossRef]

58. Montgomery, D.C.; Peck, E.A.; Vining, G.G. Introduction to Linear Regression Analysis, 5th ed.; John Wiley \& Sons: Hoboken, NJ, USA, 2012. Available online: https:/ / www.dropbox.com/sh/o9hxoa4wlo97zpe/AACbm6LetQowrpUgX4vUxnoDa?dl=0 (accessed on 3 October 2021). 